\title{
Terrestrial climate variability and seasonality changes in the Mediterranean region between 15000 and 4000 years BP deduced from marine pollen records
}

\author{
I. Dormoy ${ }^{1,2}$, O. Peyron ${ }^{1}$, N. Combourieu Nebout ${ }^{2}$, S. Goring ${ }^{3}$, U. Kotthoff ${ }^{4,5}$, M. Magny ${ }^{1}$, and J. Pross ${ }^{4}$ \\ ${ }^{1}$ Laboratory of Chrono-Environnement, UMR CNRS 6249, University of Franche-Comté, 16 route de Gray, \\ 25030 Besançon, France \\ ${ }^{2}$ Laboratory of Sciences of Climate and Environment, UMR 1572 CEA-CNRS-UVSQ, domaine du CNRS, \\ avenue de la Terrasse, 91198 Gif-sur-Yvette, France \\ ${ }^{3}$ Department of Biological Sciences, Simon Fraser University, 8888 University Drive, Burnaby, British Columbia, \\ V5A 1S6, Canada \\ ${ }^{4}$ Institute of Geosciences, University of Frankfurt, Altenhöferallee 1, 60438 Frankfurt, Germany \\ ${ }^{5}$ Department of Geosciences, Hamburg University, Bundesstrasse 55, 20146 Hamburg, Germany
}

Received: 26 January 2009 - Published in Clim. Past Discuss.: 27 February 2009

Revised: 14 September 2009 - Accepted: 15 September 2009 - Published: 19 October 2009

\begin{abstract}
Pollen-based climate reconstructions were performed on two high-resolution pollen marines cores from the Alboran and Aegean Seas in order to unravel the climatic variability in the coastal settings of the Mediterranean region between 15000 and 4000 years BP (the Lateglacial, and early to mid-Holocene). The quantitative climate reconstructions for the Alboran and Aegean Sea records focus mainly on the reconstruction of the seasonality changes (temperatures and precipitation), a crucial parameter in the Mediterranean region. This study is based on a multi-method approach comprising 3 methods: the Modern Analogues Technique (MAT), the recent Non-Metric Multidimensional Scaling/Generalized Additive Model method (NMDS/GAM) and Partial Least Squares regression (PLS). The climate signal inferred from this comparative approach confirms that cold and dry conditions prevailed in the Mediterranean region during the Oldest and Younger Dryas periods, while temperate conditions prevailed during the Bølling/Allerød and the Holocene. Our records suggest a West/East gradient of decreasing precipitation across the Mediterranean region during the cooler Late-glacial and early Holocene periods, similar to present-day conditions. Winter precipitation was highest during warm intervals and lowest during cooling phases. Several short-lived cool intervals (i.e. Older Dryas, another oscillation after this one (GI-1c2), Gerzensee/Preboreal
\end{abstract}

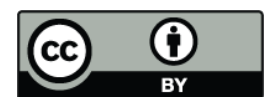

Correspondence to: I. Dormoy (isabelle.dormoy@univ-fcomte.fr)
Oscillations, $8.2 \mathrm{ka}$ event, Bond events) connected to the North Atlantic climate system are documented in the Alboran and Aegean Sea records indicating that the climate oscillations associated with the successive steps of the deglaciation in the North Atlantic area occurred in both the western and eastern Mediterranean regions. This observation confirms the presence of strong climatic linkages between the North Atlantic and Mediterranean regions.

\section{Introduction}

Research on the natural climate variability during the recent decades has been immensely stimulated by the increasing manifestation of anthropogenic climate change. Such research can provide support in evaluating future climate scenarios and as such may be instrumental in extending the lead time for adaptation (e.g. Alley et al., 2003; Mayewski et al., 2004; IPCC, 2007). The Mediterranean region is particularly sensitive to short-term climate change due to its intermediate position between the higher-latitude (i.e. North Atlanticinfluenced) and lower-latitude (i.e. monsoonally influenced) climate systems. Consequently, future climate change can be expected to be particularly strong in this region and will likely have a strong impact on terrestrial ecosystems (Cheddadi et al., 2001).

The present-day Mediterranean climate is characterised by a strong seasonality, with warm to hot, dry summers and

Published by Copernicus Publications on behalf of the European Geosciences Union. 


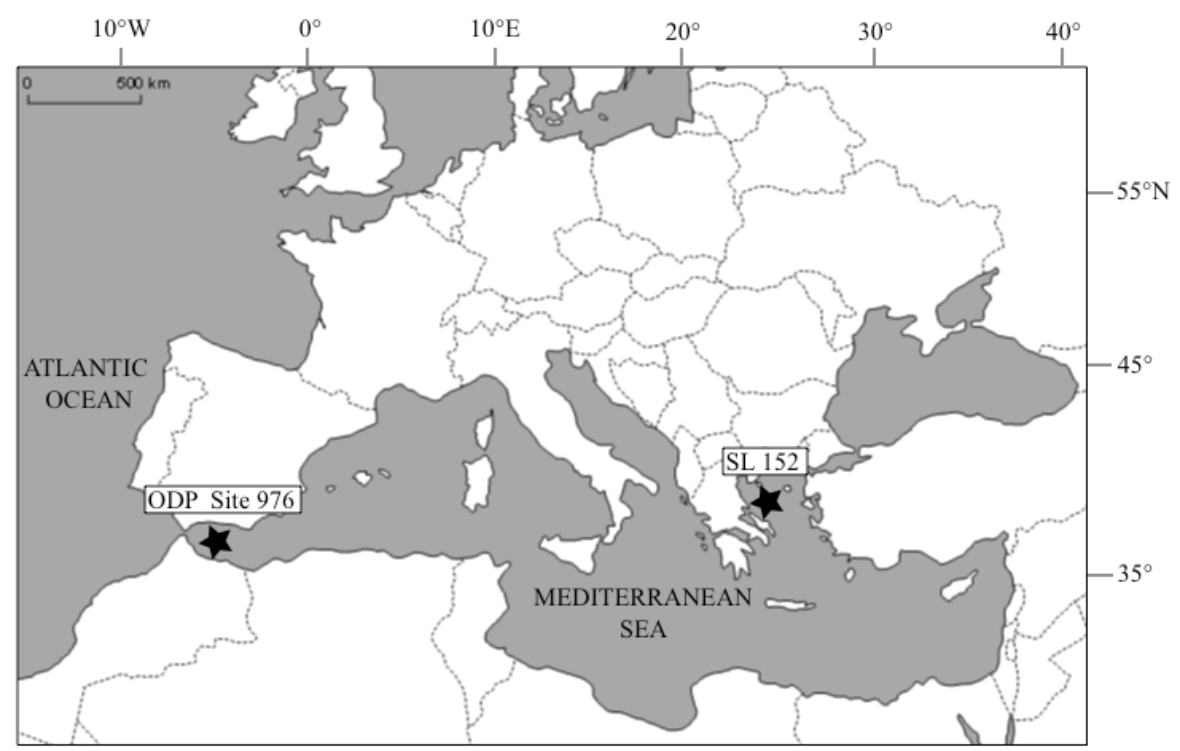

Fig. 1. Map of the Mediterranean Sea with locations of the cores ODP 976 and SL 152 (dark stars).

mild wet winters (Quézel and Médail, 2003; Lionello et al., 2006). Both terrestrial (i.e. pollen, ostracods, speleothems, lake-levels) and marine (i.e. planktic foraminifera, dinoflagellate cysts, coccoliths) proxies show that the Mediterranean region experienced very different climatic and environmental conditions during the Lateglacial and much of the Holocene, and that these climate changes differ significantly across the Mediterranean from north to south, and from west to east (e.g. Wijmstra, 1969; Pons and Reille, 1988; Zonneveld, 1996; Combourieu Nebout et al., 1998; Geraga et al., 2000; Colmenero-Hildago et al., 2002; Pérez-Folgado et al., 2003; Lawson et al., 2004; Drescher-Schneider et al., 2007; Davis and Stevenson, 2007; Magny et al., 2003, 2006b, 2007; Zanchetta et al., 2007; Kotthoff et al., 2008a, b). The quantitative paleoclimatic reconstructions inferred from pollen and chironomids records (e.g. Huntley et al., 1999; Davis et al., 2003; Heiri et al., 2007; Kotthoff et al., 2008a, b; Larocque and Finsinger, 2008), along with model simulations (e.g. Wiersma and Renssen, 2006; Brewer et al., 2007b) also indicate complex climate trends and regional climate patterns across the Mediterranean region for the last 15000 years BP. A key parameter within this climatic evolution is the seasonal distribution of temperature and precipitation (Rohling et al., 2002; Tzedakis, 2007).

In view of the above, we here aim to reconstruct the climatic trends and estimate the magnitude of temperature and precipitation changes in the Mediterranean region over the past 15000 years BP; moreover, we explore the extent of climatic linkages between the North Atlantic and Mediterranean regions. Our reconstructions are based on quantitative climate estimates derived from two high-resolution pollen records in the eastern (core SL 152; Kotthoff et al., 2008a, b) and western (ODP Leg 161 Site 976; Combourieu-Nebout et al., 1999, 2002) Mediterranean region. The quantitative climate estimates were performed with a special emphasis to reconstructing changes in seasonality, summer and winter temperatures, and summer and winter precipitation. Because each of the different procedures used in the climatic interpretation of paleoecological signals has its own set of advantages and limitations (Birks and Birks, 2006; Brewer et al., 2007a), we here follow an approach that integrates the climate data inferred from three quantitative methods. Similar approaches have been successfully applied to other regions and time intervals (e.g. Peyron et al., 2005; Brewer et al., 2008). It has been shown to yield more precise and robust climate estimates than approaches that relied on only one method (e.g. Lotter et al., 2000; Peyron et al., 2000, 2005, 2006; Brewer et al., 2008). Here, the Modern Analogue Technique (MAT; Guiot, 1990), the well-known Partial Least Squares regression (PLS; Wold et al., 1984) and the recently developed Non-Metric Multidimensional Scaling/Generalized Additive Model (NMDS/GAM; Goring et al., 2009) methods are used.

\section{Data and methods}

This study is based on two well-dated high-resolution pollen records from marine cores located along a West/East gradient across the Mediterranean Sea (Fig. 1). Core ODP Leg 161 Site 976 (Combourieu-Nebout et al., 1999, 2002, 2009) was retrieved from the Alboran Sea located between South Iberia and North Africa $\left(36^{\circ} 12^{\prime} \mathrm{N}, 4^{\circ} 18^{\prime} \mathrm{W}, 1108 \mathrm{~m}\right.$ water depth). The lands bordering the Alboran Sea are dominated 
by mountains composed of the Baetic Sierras (Spain) and the Rif (Morocco). The modern Alboran Sea hydrology is marked by an antiestuarine circulation. The Mediterranean intermediate and deep saline waters leave the Mediterranean Sea from the East to the West through the Gibraltar strait (Béthoux and Prieur, 1984).

Core SL 152 (Kotthoff et al., 2008a, b) was obtained from the Mount Athos Basin, Northern Agean Sea $\left(40^{\circ} 19^{\prime} \mathrm{N}\right.$, $24^{\circ} 36^{\prime} \mathrm{E}, 978 \mathrm{~m}$ water depth). Pollen carried into the Mount Athos Basin through aerial and fluvial transport is predominately derived from the northern borderlands of the Aegean Sea (Kotthoff et al., 2008a, b).

The chronology is based on six ${ }^{14} \mathrm{C}$ dates in Alboran Sea and seven in Aegean Sea between 15000 and 4000 years BP (Fig. 2; Combourieu-Nebout et al., 1999, 2002; Kotthoff et al., 2008a, b). The dates were corrected assuming reservoir ages of 400 years in the core ODP 976 to account for ${ }^{14} \mathrm{C}$ reservoir age of the modern Alboran Sea surface water. And, the dates in the core SL 152 have been corrected by 400 years, except the ${ }^{14} \mathrm{C}$ date "12 $430 \mathrm{yr} \mathrm{BP"} \mathrm{in} \mathrm{depth} 505 \mathrm{~cm}$, following Siani et al. (2001). And in both cores, the dates were converted into calendar years after Stuiver et al. (1998) and Fairbanks et al. (2005). The sampling resolution ranges from 40 to 250 years for the core from ODP Site 976, and from 30 to 180 years for core SL 152 with the highest resolution of 270 to $350 \mathrm{~cm}$. The preparation of pollen samples was carried out following the classical protocol (Faegri and Iversen, 1964).

\subsection{Pollen data}

Figure 2 and Table 1 summarize the main vegetation changes in the Alboran and the Aegean Seas over the past 15000 years BP. In-depth descriptions of the palynological changes documented in both cores are available in CombourieuNebout et al. (2009) for the Alboran Sea and in Kotthoff et al. (2008a, b) for the Aegean Sea.

Both cores have high proportions of Artemisia, Chenopodiaceae and Ephedra to $14.7 \mathrm{kyr} B \mathrm{P}$. Temperate forest species are all found in low proportions (Quercus, Alnus, Betula, Populus, Salix, Carpinus and Fagus, all $<10 \%$ ). From 14.7 to $12.5 \mathrm{kyr} \mathrm{BP}$, pollen taxa associated with deciduous forests increase to $45 \%$, and the semidesert taxa such as Artemisia decrease rapidly. Between 12,5 to $11.7 \mathrm{kyr} \mathrm{BP}$, during the Younger Dryas an increase of Artemisia, Chenopodiaceae and Ephedra are associated with a decrease of Quercus. During short-lived events occurred within the Lateglacial, semi-desert taxa increase and the temperate forest taxa decrease slightly. From 11.7 to 4 kyr BP, Quercus and temperate forest taxa increase to $70 \%$ (Mediterranean taxa increase too). During short-lived events (possibly corresponding to the Preboreal Oscillation and the 8.2 ka event) the Cichorioideae and Chenopodiaceae increase slightly.

\subsection{Climate reconstruction methods}

The quantitative reconstructions are derived from the Modern Analogue Technique (MAT), the Non-Metric Multidimension Scaling/Generalized Additive Model (NMDS/GAM) method, and the Partial Least Square regression (PLS) approach.

The MAT (Guiot, 1990) uses modern pollen surface samples and the corresponding modern climate to infer paleoclimate parameters. The method consists of selecting a set of modern samples (or analogues) that most closely resemble each fossil pollen sample. The dissimilarity between each fossil sample and modern pollen assemblage is evaluated by a chord distance (Guiot, 1990). Usually, the ten modern spectra that have the smallest distance from a given pollen spectrum are considered as the best modern analogues and subsequently used for the reconstruction. If the chord distance is above a threshold defined by a Monte-Carlo method (Guiot, 1990), the modern samples are considered as poor analogues and not taken into account in the reconstruction. Estimates of climatic parameters are obtained by using a weighted average of the values for all selected best modern analogues, where the weights used are the inverse of the chord distance.

The NMDS/GAM method (Goring et al., 2009) reconstructs climate parameters by applying an NMDS ordination to the modern pollen data and fitting a GAM for the climate parameter of interest to the NMDS ordination output. This technique reduces the effects of co-linearity among pollen taxa, accounts for species gradients and, since NMDS is a non-parametric ordination procedure, reduces the likelihood that the statistical assumptions common in standard pollenbased reconstruction methods - such as normal distributions for pollen proportions - will be violated by the methods.

The PLS method used in this study is a technique that eliminates co-linearity among predictor variables through the selection of orthogonal components obtained from the singular decomposition of the response (climate parameters) and predictor (pollen taxon) variables. This improves the similar principal components regression since the response variable is specifically taken into account in the initial component decomposition (Wold et al., 1984). The PLS method is commonly used and may be paired with weighted averaging (ter Braak and Juggins, 1993), although this does not always improve the prediction results (Goring et al., 2009).

All three methods are based on present-day environmental conditions and therefore require high-quality, taxonomically consistent modern pollen and climate datasets. The modern pollen dataset used here is based on 3542 modern samples, among which more than 2000 are from the Mediterranean region (Bordon et al., 2009). For the present study, bisaccate pollen (Pinus) was removed from the pollen sums because it is generally overrepresented in marine pollen assemblages.

The three methods were used to reconstruct the annual precipitation (PANN), seasonal precipitation (PWinter is the sum of the precipitation occurring from December 

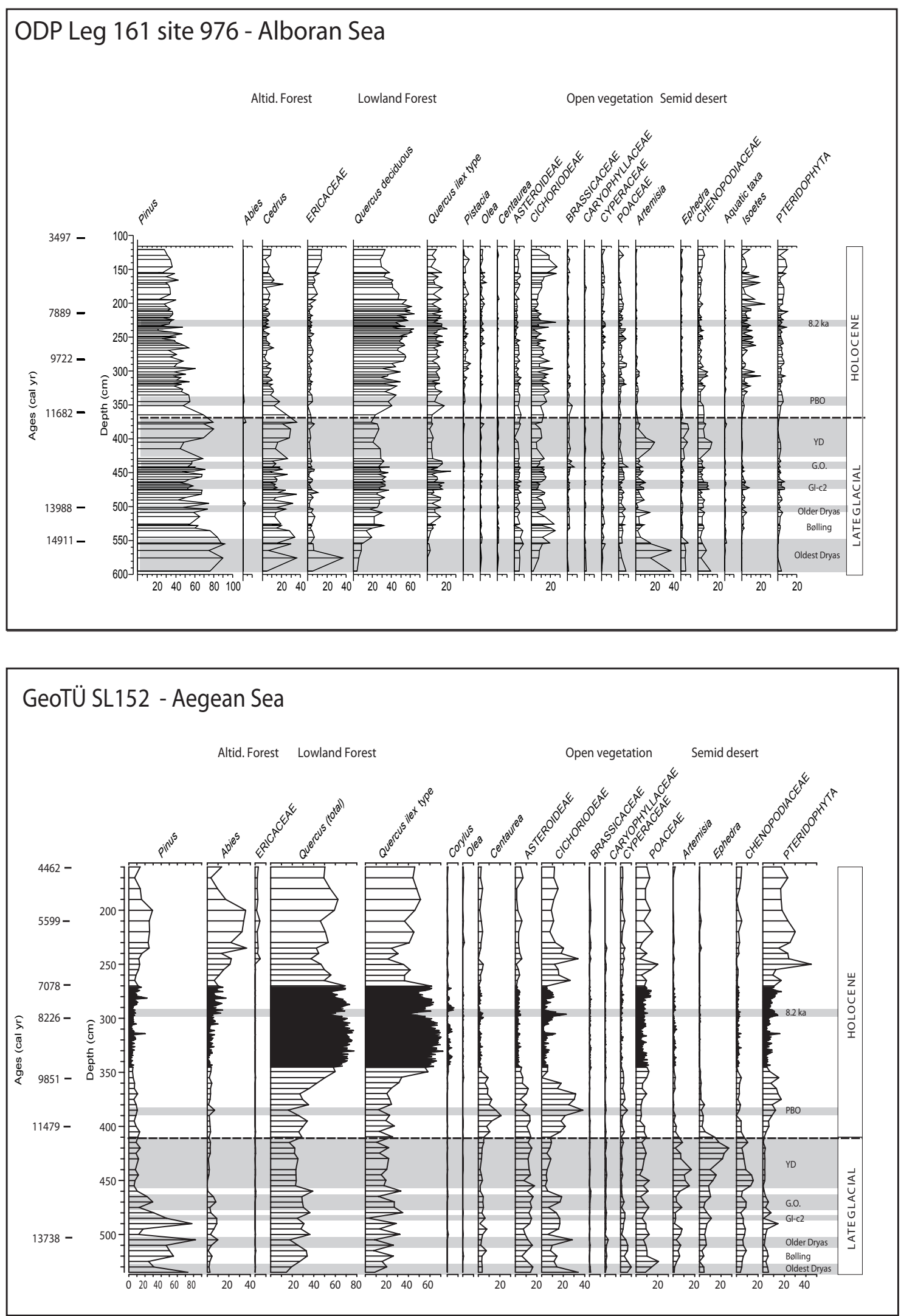

Fig. 2. Simplified pollen diagrams from cores ODP Leg 161 Site 976 (Alboran Sea; Combourieu-Nebout et al., 2002, 2009) and GeoTü SL 152 (Aegean Sea; Kotthoff et al., 2008a, b). Horizontal grey bands mark cooling phases. 
Table 1. Vegetation changes of core ODP Leg 161 site ODP 976 and core SL 152.

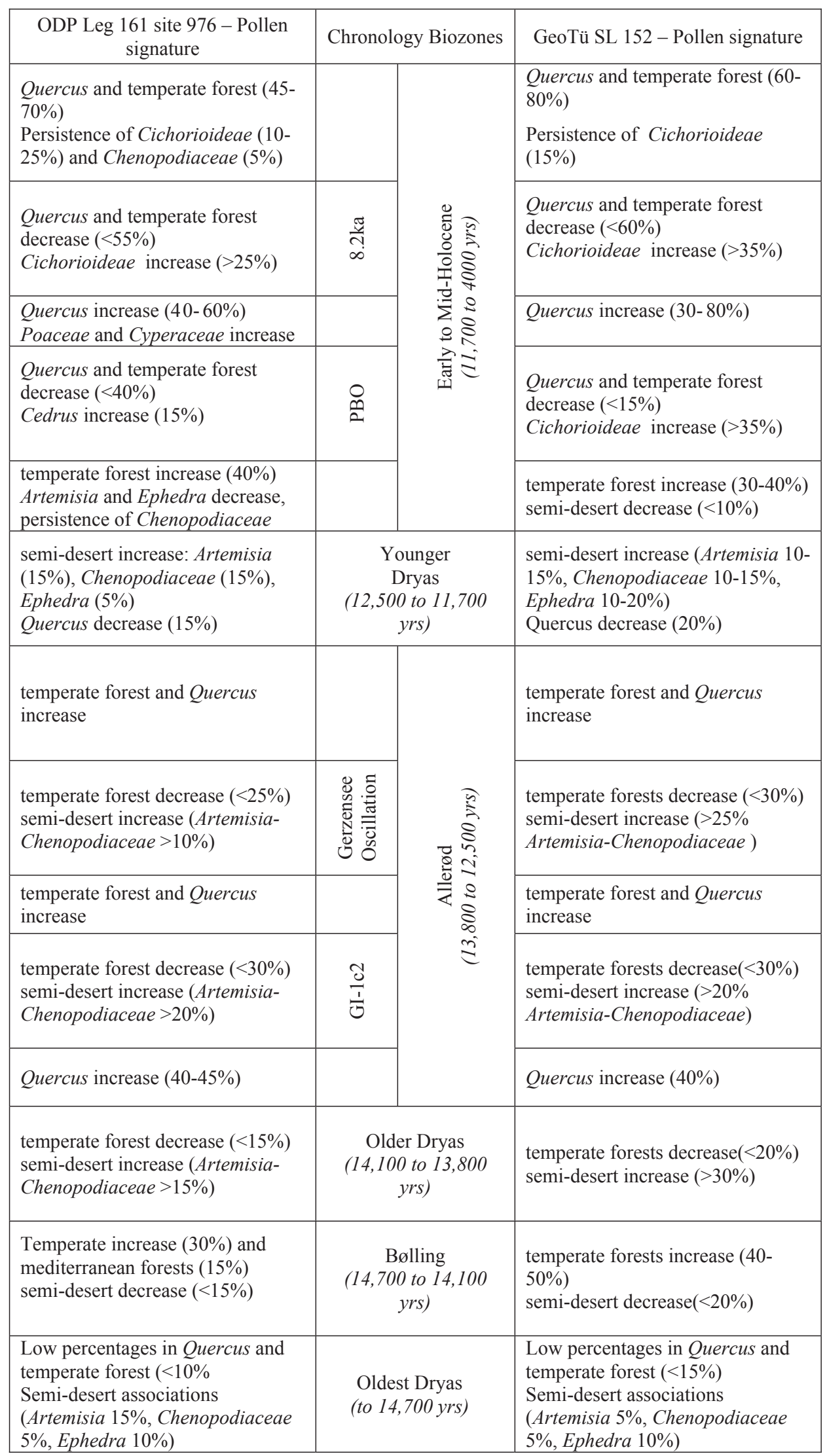


to February inclusive, and PSummer of the precipitation sum from June to August inclusive), mean temperature of the coldest month (MTCO) and mean temperature of the warmest month (MTWA).

\section{Results and discussion}

\subsection{Oldest Dryas (to 14.7 kyr BP)}

The pollen data indicate cold and arid conditions for the borderlands of the Alboran and Aegean Seas (Figs. 3 and 4) before $14.7 \mathrm{kyr} \mathrm{BP}$. The quantitative reconstructions confirm the prevalence of cold and dry conditions before $14.7 \mathrm{kyr} B P$ in the Alboran Sea, with low winter (up to $-10^{\circ} \mathrm{C}$ ) and summer (up to $14^{\circ} \mathrm{C}$ ) temperatures and winter precipitation values (Fig. 3). High percentages of semi-desert species (Artemisia and Chenopodiaceae) in both records are in agreement with terrestrial pollen records from Tenaghi Philippon in Greece (Wijmstra, 1969), Lake Maliq in the Balkans (Bordon et al., 2009) and marine pollen records from western Iberia (Naughton et al., 2007). Low temperatures during this period are supported by foraminifera abundance data from the Myrtoon basin (SW Aegean Sea), where cold species dominate the assemblages (Geraga et al., 2000). Reconstructed winter anomalies are in agreement with estimates from Lago Grande di Monticchio in Central Italy (Huntley et al., 1999). Annual precipitation values at $15 \mathrm{kyr}$ BP reconstructed from the Alboran pollen record are slightly lower than today. This result is similar to the situation reconstructed for the Balkans (Bordon et al., 2009). It is also supported by previous pollen-based climate reconstructions from the Alboran Sea (Kageyama et al., 2005).

In the Aegean Sea, both NMDS/GAM and MAT methods indicate mean temperature of the coldest month around $0^{\circ} \mathrm{C}$, mean temperature of the warmest month around $21^{\circ} \mathrm{C}$, and annual precipitation $100 \mathrm{~mm}$ lower than modern precipitation values (Fig. 4). The PLS method indicate strongly different values (such discrepancies in the methods are discussed in detail in the part 4 of the current study). The transition between the Oldest Dryas and the Bølling/Allerød is more pronounced and rapid in the reconstructions from the Alboran Sea than in the Aegean Sea. This dramatic transition seen in the Alboran record is similar to those seen in marine and terrestrial records from western Spain (Naughton et al., 2007).

\subsection{Bølling/Allerød (14.7 to $12.5 \mathrm{kyr}$ BP)}

From 14.7 to $12.5 \mathrm{kyr} \mathrm{BP}$, both marine pollen records indicate an early temperate phase marked by the expansion of deciduous and Mediterranean forest elements (Fig. 2 and Table 1). This suggests warm, moist climate conditions for the borderlands of the Western and Eastern Mediterranean Sea (Combourieu-Nebout et al., 1999; Zonneveld, 1996). The presence of Pistacia in the Alboran Sea record during this period suggests a mild winter since Pistacia is not found at sites with minimum temperatures below $5^{\circ} \mathrm{C}$ (Mudie et al., 2002; Quézel and Medail, 2003).

Warm, moist conditions are also evident from the pollenbased climate reconstructions during this period (Figs. 3 and 4). They indicate the establishment of a sub-seasonal "Mediterranean" rainfall regime with hot, dry summers and cool, wet winters (PWinter: 130-250 mm, PSummer: 50 to $100 \mathrm{~mm}$ ), less marked in the Aegean Sea. Our results from the Alboran Sea (MAT) suggest that a seasonality comparable to modern condition in that region (with high winter precipitation and low summer precipitation) first occurred at $14.7 \mathrm{kyr} \mathrm{BP}$ and is comparable in trend but not in magnitude to modern seasonality observed in the Alboran Sea. The transition to modern precipitation seasonality is not observed in the Aegean core, SL 152, suggesting that it may have taking place earlier than 15 kyr BP (Fig. 4).

The results obtained with three methods shows at least three rapid and abrupt short-term events which punctuate the Late-glacial interstadial in the Alboran and Aegean Seas at $14.1-13.9,13.5-13.4$. and $13-12.6 \mathrm{kyr} \mathrm{BP}$, and may be related to the Older Dryas, Greenland Interstadial-1c2 (GI-1c2) and the Gerzensee Oscillation respectively (Rasmussen et al., 2006; Brauer et al., 2000). Here, the pollen-based precipitation reconstructions show sharp drops in annual and summer precipitation for the borderlands of the Aegean Sea, and smaller drops in the borderlands of the Alboran Sea that correlate with the GI-1d (Older Dryas) and GI-1b (Gerzensee oscillation) events in the GRIP and NGRIP records (Figs. 3 and 4; Björck et al., 1998; Rasmussen et al., 2006). The Older Dryas shows a negative anomaly of $2-6^{\circ} \mathrm{C}$ for MTWA and MTCO, a drop of 100-200 mm for PANN, and between 25 to $100 \mathrm{~mm}$ for PWinter in the both cores. During the GI$1 \mathrm{c} 2$, the MTCO and MTWA decrease between 2 and $5^{\circ} \mathrm{C}$, the Annual and Winter Precipitations show a drop of 50 to $200 \mathrm{~mm}$ in the Alboran and Aegean Seas. And the Gerzensee Oscillation shows a drop of $2-3^{\circ} \mathrm{C}$ for the Mean Temperature of the Warmest and the Coldest Months, PANN and PWinter decrease between 50 and $200 \mathrm{~mm}$ in the cores ODP 976 and SL 152. For each oscillations, the PSummer increase between 50 to $100 \mathrm{~mm}$ in the Aegean Sea and decrease between 25 to $50 \mathrm{~mm}$ in the Alboran Sea. These successive oscillations are well documented in Northern and Central Europe (Lotter et al., 1992; Peyron et al., 2005; Magny et al., 2006a), and to a lesser extent, in the Mediterranean region (Asioli et al., 1999; Magny et al., 2006b; Drescher-Schneider et al., 2007).

Our study reveals strong temperature responses to these events in the Aegean Sea pollen record, with drops of up to $4^{\circ} \mathrm{C}$ in winter temperature, and equivalent, but somewhat earlier changes in the Alboran Sea. The precipitation record shows a similar pattern, with smaller changes in the Alboran resulting in an overall precipitation gradient from East to West (with dryer conditions in the East) that matches the 


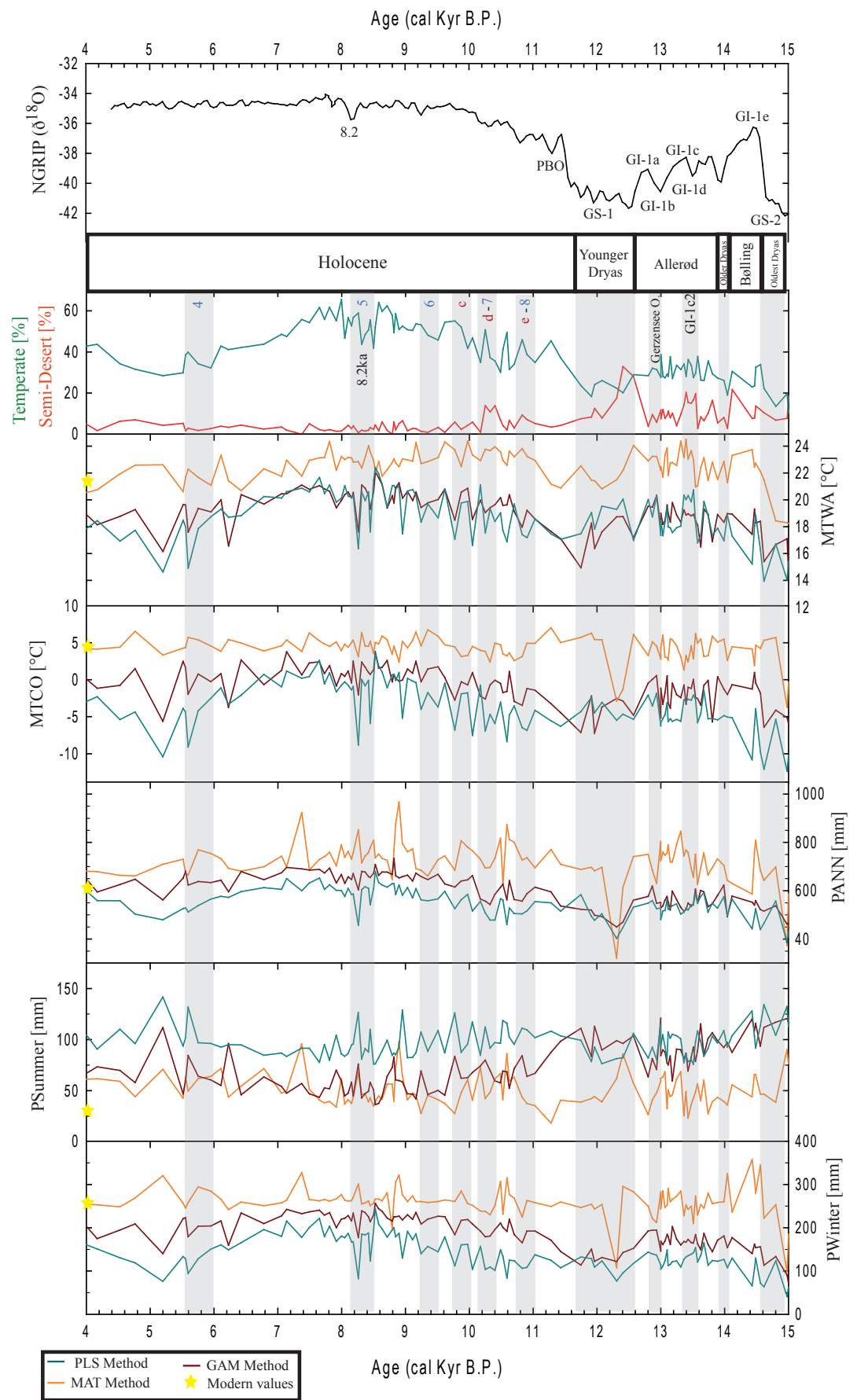

Fig. 3. Climate reconstructions for the borderlands of the Alboran Sea based on the pollen data from core ODP Leg 161 Site 976 (Combourieu-Nebout et al., 2009). Percentages of temperate taxa and semi-desert taxa in percent are marked in green and red, respectively. MTWA=mean temperature of the warmest month, $\mathrm{MTCO}=$ mean temperature of the coldest month. Annual (PANN), winter (PWinter) and summer (PSummer) precipitation is indicated as reconstructed with the MAT, NMDS/GAM and PLS methods. The RMSE values for MAT are 2.55 for MTWA, 4.02 for MTCO, 186.70 for PANN, 16.01 for PSummer and 27.02 for PWinter. The RMSEP values for NMDS/GAM and PLS (in this order) are 3.04 and 3.68 for MTWA, 4.94 and 6.39 for MTCO, 227.27 and 271.92 for PANN, 50.39 and 67.52 for PSummer, and 77.69 and 91.59 for PWinter. Horizontal grey bands correspond to cool climate oscillations: Oldest Dryas, Older Dryas, GI-1c2, Gerzensee oscillation, Younger Dryas, $8.2 \mathrm{ka}$ event are indicated in black. The short-term events defined by Bond et al. (1997) are named "4 to 8 " in blue. The events indicated by Favaretto et al. (2008) are named "c, d and e" in red. NGrip $\delta^{18}$ O after North Greenland Ice Core Project members (2004). 
modern gradient in the Mediterranean. The study of new sites, particularly in the center of the Mediterranean Sea, could test this assumption.

\subsection{Younger Dryas (12.5 to $11.7 \mathrm{kyr}$ BP)}

A rapid decrease in temperature and precipitation (annual and winter) occurred during the Younger Dryas in both the records (Figs. 3 and 4). During this interval, Artemisia pollen percentages increased in the Alboran $(+20 \%)$ and Aegean Sea cores $(+30 \%)$ indicating a pronounced aridity (Fig. 2). These results are in agreement with increases in semi-desert pollen taxa recorded in the marine pollen cores MD 902043 (Alboran Sea; Fletcher and Sanchez-Goñi, 2008) and MD 90-917 (Adriatic Sea; Combourieu-Nebout et al., 1998, 1999), and in the terrestrial pollen record from Padul, Spain (Pons and Reille, 1988). In the Alboran Sea, winter temperature values of approximately -2 to $-4^{\circ} \mathrm{C}$ during the Younger Dryas correspond to a strong decline in temperatures with MTCO anomalies of -8 to $-10^{\circ} \mathrm{C}$, while the anomaly of MTWA is around $-6^{\circ} \mathrm{C}$ with the PLS and NMDS/GAM methods (Fig. 3). In general, the amplitude of the Younger Dryas cooling event is larger for the MAT reconstruction than the NMDS/GAM and PLS methods. The results obtained with the MAT for Mean Temperature of the Coldest Month and Annual Precipitation are however in agreement with those simulated by Renssen et al. (2001).

For the Younger Dryas, the temporal resolution of the Aegean core SL 152 is higher than that of the Alboran core. Hence, the MAT appears to indicate the presence of three distinct climate phases during the Younger Dryas (Fig. 4) with colder conditions during the first and third phases between 12.6 to $12.4 \mathrm{kyr}$ and 12.2 to $11.7 \mathrm{kyr} \mathrm{BP}$ (MTCO: $-5^{\circ} \mathrm{C}$ and $-1^{\circ} \mathrm{C}$ ). The middle phase of the Younger Dryas, based on the MAT reconstruction, between 12.4 to $12.2 \mathrm{kyr} \mathrm{BP}$ shows an temperature increase of $3-5^{\circ} \mathrm{C}$ when compared to the colder phases. This pattern is in agreement with GRIP and NGRIP ice-core records (Björck et al., 1998; Rasmussen et al., 2006), pollen-based reconstructions from the Jura (Peyron et al., 2005) and the Balkans (Bordon et al., 2009), and chironomid-based reconstructions from North Italy (Larocque and Finsinger, 2008).

In the borderlands of the Alboran and Aegean Seas, the mean temperature of the coldest month ranged from $-5^{\circ} \mathrm{C}$ to $0^{\circ} \mathrm{C}$ during the Younger Dryas. These are close to values from Central Italy (Huntley et al., 1999), the central Balkans (Bordon et al., 2009) but colder than model simulations (Renssen et al., 2001). In the Alboran and Aegean Seas, our three pollen-based climate reconstructions show pronounced declines in all three precipitation parameters, particularly for annual and winter precipitation (PANN decline: $\sim 400 \mathrm{~mm}$; PWinter decline: $\sim 100 \mathrm{~mm}$ ). Thus, the Younger Dryas event seems to affect principally the winter season (Denton et al., 2005).
The cooling during the Younger Dryas seems to have had little effect on summer climate parameters (both precipitation and temperature) in the borderlands of the Aegean and Alboran Seas. This interpretation is well consistent with the current interpretation of the Younger Dryas event by Renssen et al. (2001). It is of note that wet summer conditions are depicted (1) in the Aegean Sea with the Modern Analogue Technique model and (2) in the Alboran Sea with the NMDS/GAM model. In the Balkans at Lake Maliq, a pollen-inferred climate reconstruction also shows increased precipitation seasonality during the Younger Dryas, characterised by arid winter conditions and wetter summer conditions (Bordon et al., 2009). The present-day summer conditions in the Mediterranean area are relatively dry due to downward motion in the atmosphere associated with areas of high surface pressure, such as the Azores High. During the Younger Dryas, these high-pressure centers may have moved slightly to the South, enabling depressions to reach the Mediterranean more easily during the summer. However, these interpretations should be treated with caution since the underlying climate reconstructions may also be a result of bias in the modern pollen dataset: Artemisia-dominated pollen assemblages are today predominantly found in Asian steppes (including Tibet and Kazakhstan) characterized by low annual precipitation and precipitation maxima in the spring or summer. This study should confirm this interpretation: the wet conditions reconstructed for the borderlands of the Aegean Sea during the Younger Dryas are probably due to the seasonality regime of the modern semi-desert modern pollen assemblages. Only the PLS method indicates a decline in summer precipitation, in both the Alboran and Aegean Seas (Figs. 3 and 4). The summer precipitation values simulated by the REMO model present a negative anomaly compared to present day values over the Europe (Renssen et al., 2001). But the use of another method such as the inverse modelling method which includes a vegetation model could help to better understand this seasonality pattern (Guiot et al., 2000).

\subsection{Early to mid-Holocene (11.7 to 4 kyr BP)}

\subsubsection{Transition younger Dryas/Holocene (11.7 to $9.5 \mathrm{kyr}$ BP)}

The pollen data from the Alboran and Aegean cores clearly indicate warm and moist conditions through this interval, which was climatically much more stable than the Lateglacial (Figs. 3 and 4). Both pollen diagrams show a significant expansion of Quercus and temperate taxa (Fig. 2), with the development of temperate forests resulting from an increase in temperature and moisture (Figs. 3 and 4; Combourieu-Nebout et al., 1999, 2009; Kotthoff et al., 2008a, b).

Between 11.7 and $9.5 \mathrm{kyr} \mathrm{BP}$, our quantitative climate reconstructions results indicate a trend toward increasing 


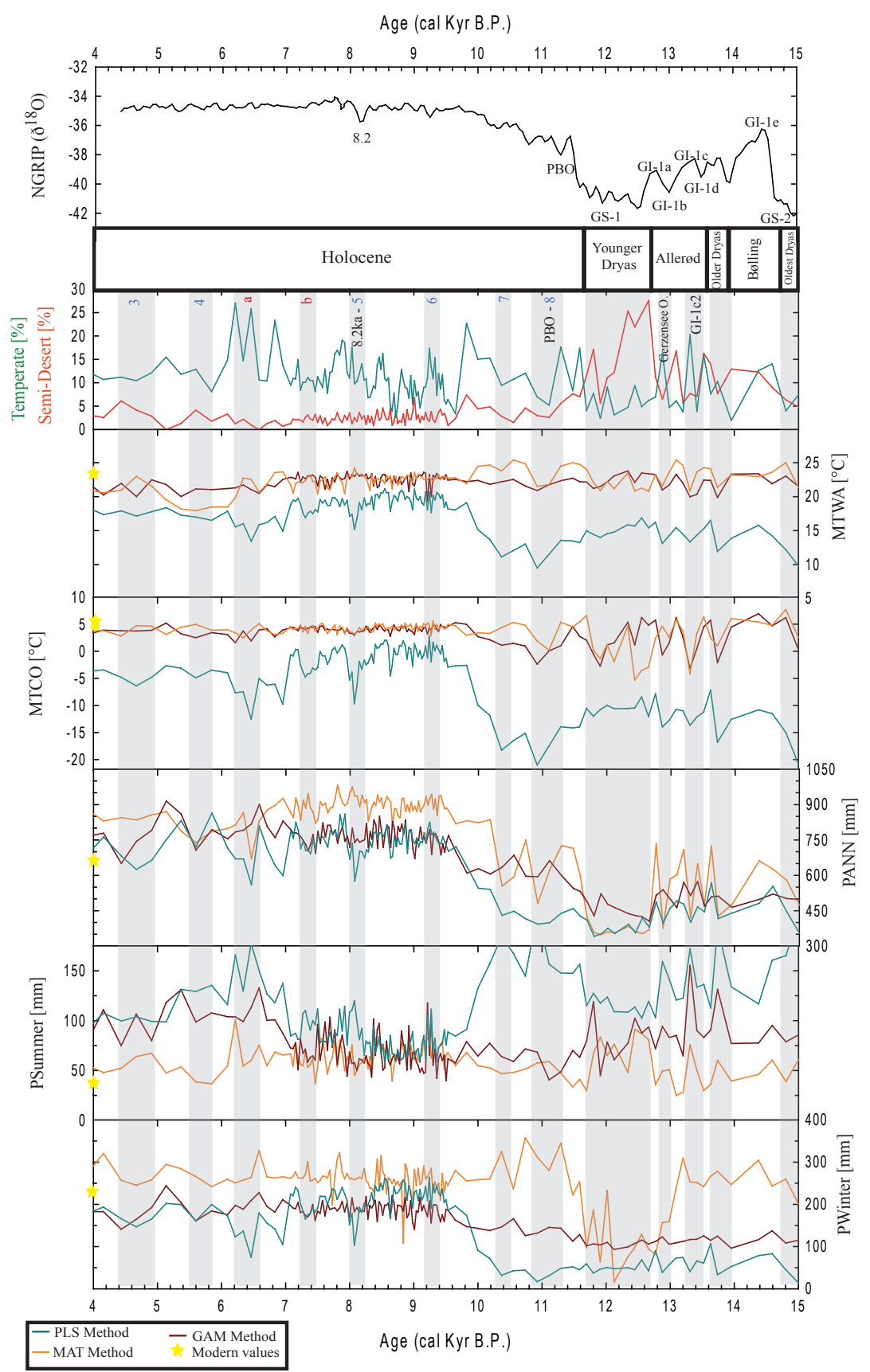

Fig. 4. Climate reconstructions for the borderlands of the Aegean Sea based on the pollen data from core SL 152 (Kotthoff et al., 2008 a, b). Percentages of temperate taxa and semi-desert taxa are marked in green and red, respectively. MTWA=mean temperature of the warmest month, MTCO=mean temperature of the coldest month. Annual (PANN), winter (PWinter) and summer (PSummer) precipitation is indicated as reconstructed with the MAT, NMDS/GAM and PLS methods. The RMSE values for MAT are 2.55 for MTWA, 4.02 for MTCO, 186.70 for PANN, 16.01 for PSummer and 27.02 for PWinter. The RMSEP values for NMDS/GAM and PLS (in this order) are 3.04 and 3.68 for MTWA, 4.94 and 6.39 for MTCO, 227.27 and 271.92 for PANN, 50.39 and 67.52 for PSummer, and 77.69 and 91.59 for PWinter. Horizontal grey bands correspond to cool climate oscillations: Oldest Dryas, Older Dryas, GI-1c2, Gerzensee oscillation, Younger Dryas, Preboreal oscillation (PBO), $8.2 \mathrm{ka}$ event are indicated in black. The short-term events defined by Bond et al. (1997) are named " 3 to 8 " in blue. The events indicated by Geraga et al. (2000) are named "a and b" in red. NGrip $\delta^{18} \mathrm{O}$ after North Greenland Ice Core Project members (2004). 
precipitation in the borderlands of the eastern and western Mediterranean Sea (PANN: 500-700 mm for the Alboran Sea, $400-800 \mathrm{~mm}$ for the Aegean Sea; PWinter: 100 $250 \mathrm{~mm}$ for the Alboran and Aegean Seas). Summer precipitations remained relatively high and stable during the transition from the Younger Dryas to the Holocene, while the winter and summer temperatures increase slightly. Although precipitation increased, the gain in effective precipitation was likely to be small because rising temperatures trend to result in increased evaporation (Renssen and Isarin, 2001). The amplitude of the transition from the Late-glacial to the Holocene is largest in the core from the Aegean Sea with regard to winter temperatures. This observation is consistent with the results of Renssen and Isarin (2001) for the same interval. In the borderlands of the Alboran Sea, the summer warming was likely more important than the January warming: the $\mathrm{MTCO}$ reaches $5^{\circ} \mathrm{C}$ at $11.5 \mathrm{kyr} \mathrm{BP}$ with the MAT, this result is well consistent with the value obtained by Renssen and Isarin (2001) for Spain using the ECHAM4 atmospheric general circulation model, and $2^{\circ} \mathrm{C}$ upper than the value obtained for Southwest in Europe by Davis et al. (2003) from pollen data.

In the borderland of the Aegean Sea, the warming trend was interrupted by a short-lived cooling indicated by the MAT method between 11.4 and 10.9 kyr BP (Fig. 4) that may be related to the Preboreal Oscillation (PBO; Björck et al., 1997), a response to meltwater pulses and a sudden decrease in solar activity (Magny et al., 2007). In northern Europe, the PBO is marked by a $\sim 4-5^{\circ} \mathrm{C}$ decline in temperature in association with low annual and winter precipitation (Davis et al., 2003). Here too, dryer conditions and a more complex pattern in summer (Fig. 4) are in agreement with declining lake-levels inferred from the Lake Accesa record in Central Italy (Magny et al., 2007). In the Alboran Sea core, the warming trend was interrupted by three short-term cold dry oscillations at 10.8, 10.3 and $10 \mathrm{kyr}$ BP (Fig. 3, events c, $\mathrm{d}$ and e). These temperature oscillations are also documented in foraminifera and pollen records from the western and central Mediterranean region (Favaretto et al., 2008) and in the alkenone SST records (Sbaffi et al,. 2001) (Fig. 3).

\subsubsection{Holocene optimum (9.5 to $7.5 \mathrm{kyr}$ BP)}

The early Holocene ( 9.5 to $7.5 \mathrm{kyr} \mathrm{BP}$ ) was characterized by high temperatures and moist annual and winter conditions in both the western and eastern Mediterranean regions (PetitMaire et al., 2005). Previous studies have shown that annual precipitation reached a maximum during this period both in the eastern Mediterranean region (Bar-Matthews et al., 1999; Rossignol-Strick, 1999; Kotthoff et al., 2008a, b), and in northern Africa and central Europe (Magny et al., 2002). According to the results of our study, precipitation seasonality increased strongly during this period, with winter precipitation attaining a maximum at both sites (PWinter: 200 to $300 \mathrm{~mm}$ ) and summer precipitation simultaneously reaching a minimum (PSummer: 50 to $100 \mathrm{~mm}$ ). These trends are evidenced in all three reconstruction methods applied. Jalut et al. (2009) reconstructed a similar pattern in the Western and Central Mediterranean with short dry summer periods since the beginning of the Holocene that correspond to presentday Mediterranean conditions. This pattern differs from results obtained for other geographical regions, for example in Northernmost Europe (Allen et al., 2007), and in the Eastern Mediterranean (Rossignol-Strick, 1999; Bar-Matthews et al., 2000) which found abundant year-round moisture with higher precipitation during the summer. However, such interpretation of wet summers in Eastern Mediterranean is still under debate (Tzedakis et al., 2007). Reconstructions focusing on the mid-Holocene climate (6 kyr BP) for Europe also show that the climatic response varies along a north-south gradient (Cheddadi et al., 1997; Davis et al., 2003; Cheddadi and Bar-Hen, 2009), and also between the eastern and western Mediterranean (Brewer et al., 2009).

The current study shows evidence of strong seasonality with hot dry summers and wet winters (MTWA: $20-22^{\circ} \mathrm{C}$, MTCO: $3-5^{\circ} \mathrm{C}$ ). Temperatures for the coldest and warmest months reached modern levels by $9.5 \mathrm{kyr}$ BP. In the Myrtoon Basin of the southern Aegean Sea SST values reached modern values at the same period (Geraga et al., 2000). The reconstruction of moist conditions during the early to midHolocene is consistent with speleothem evidence that shows a substantial increase in winter rainfall in Central Italy during this period (Zanchetta et al., 2007), and with marine and lacustrine records from the Nile cone (Cheddadi et al., 1995) and the central Italy (Ariztegui et al., 2000). SST reconstructions for the early Holocene do not show a clear pattern. Some authors suggest cooler conditions (Kallel et al., 1997) and others warmer conditions (Marchal et al., 2002) in the northeast Atlantic and Mediterranean. In contrast to Davis et al. (2003), and in agreement with our own study, the inferred climate for this period in a number of marine-based studies has also been warm and wet during the winter in the Mediterranean region (Rohling and De Rijk, 1999; Ariztegui et al., 2000, Myers and Rohling, 2000). In the Aegean Sea, the period from 9.5 to $7 \mathrm{kyr}$ BP represents Sapropel S1 (Ariztegui et al., 2000; Kotthoff et al., 2008a, b). Sapropels are organic-carbon-rich layers usually found intercalated with the more typical organic-poor carbonate sediments of the Mediterranean. Most of the lithostratigraphic evidence for S1 is found in marine cores of the Adriatic Sea, and the Ionian and Levantine Basins (Emeis et al., 2000). Estimates of the duration for Sapropel S1 from the Aegean are longer (9.4-6.8 kyr BP) than those from the Adriatic Sea (e.g. 8.3-6.3 kyr BP; Jorissen et al., 1993; Mercone et al., 2000).

\subsubsection{Mid-Holocene (7.5 to $4.0 \mathrm{kyr}$ BP)}

During this period, temperatures decline by $3^{\circ} \mathrm{C}$ in the western Mediterranean region whereas the annual and 
winter precipitation decrease by $\sim 50 \mathrm{~mm}$, while PSummer increases slightly by the same amount. This decline began at $\sim 7.8 \mathrm{kyr} \mathrm{BP}$ in the borderlands of the Alboran Sea and at $\sim 7.2 \mathrm{kyr}$ BP in those of the Aegean Sea (Figs. 3 and 4). A drying phase also begins at $7.9 \mathrm{kyr} \mathrm{BP}$ in Italia, in Lake Lagaccione pollen record and between 8 to $7.6 \mathrm{kyr}$ BP in Sicily, Lago di Pergusa (Jalut et al., 2009). The Mid-Holocene humid conditions ended between 7.7 to $7.2 \mathrm{kyr}$ BP in AlgeroBalearic basin (Jimenez-Espejo et al., 2008). These results are in agreement with the Alboran Sea record presented here. In Turkey (Eski Acigöl), the beginning of the dry interval is at 6.5 kyr BP (Roberts et al., 2001). Decreasing humidity seems to develop along a West-to-East gradient.

At $6 \mathrm{kyr} \mathrm{BP}$, winter temperatures are also in agreement with other temperature reconstructions in Mediterranean for the mid-Holocene period (Cheddadi et al., 1997; Davis et al., 2003; Brewer et al., 2007b; Wu et al., 2007; Davis and Stevenson, 2007). The MTWA anomaly during the midHolocene in the Aegean Sea is around $-1^{\circ} \mathrm{C}$ and the MTCO anomaly is around $0^{\circ} \mathrm{C}$ with the MAT method. These results are in agreement with the values - also obtained with the MAT - of Davis et al. (2003) in SE Europe and confirm the warming summer trend reconstructed between $7.5 \mathrm{kyr}$ BP to 4.0 kyr BP. In Alboran Sea however, we reconstruct a slight summer cooling trend between $7.5 \mathrm{kyr}$ BP to $4.0 \mathrm{kyr} \mathrm{BP}$, with MTWA anomalies between 0 to $0.5^{\circ} \mathrm{C}$. The results obtained for the Alboran Sea seems not to be agreement with the Davis et al. (2003) study which reconstruct negative summer anomalies associated to a warming summer trend from $6.0 \mathrm{kyr}$ BP to $0 \mathrm{kyr}$ BP in SW Europe. Such discrepancies can be explained by the fact that, in contrast to the current study, Davis et al. (2003) use a modified Modern Analogue Technique (Guiot, 1990), using Plant Functional Type scores (Prentice et al., 1996) to select the best modern analogues. The larger modern pollen data set used in the current study, the wide fossil dataset (more than 500 sites) used in Davis et al. (2003) and Davis and Brewer (2009), and the methodological differences (see this study) may ultimately explain the differences between the current study and those of Davis et al. (2003). Davis and Brewer (2009) found a summer temperature anomaly between $-1.5^{\circ} \mathrm{C}$ to $-0.5^{\circ} \mathrm{C}$ in Southern Europe during the mid-Holocene. They explain the pattern of cooling in South Europe and warming in North Europe already shown by Cheddadi et al. (1997), by a latitudinal insolation gradient. Davis and Brewer (2009) indicate that temperature sensitivity to both the latitudinal insolation gradient and to ice cover forcing may therefore offer an alternative perspective not just on orbital forcing of high latitude warming, but also on orbital forcing of low latitude climate. This result is in agreement with the results described in this study, but the trends differ slightly. Between $7.5 \mathrm{kyr}$ BP to $4.0 \mathrm{kyr}$ BP, the MTWA values decrease slightly in Alboran Sea and are relatively stable in Aegean Sea. The data presented in this paper seems thus not support the hypothesis of Davis and Brewer (2009). More investigation and the addition of new study sites could allow a better comparison with the results obtained by Davis and Brewer (2009) to validate or not the Davis and Brewer (2009) hypothesis.

At that time, precipitation in the borderlands of the Alboran and Aegean Seas predominantly occurred during the winter, and summers experienced increasingly dry conditions ( +50 to $75 \mathrm{~mm} / \mathrm{yr}$ as evidenced in all three methods). Wu et al. (2007) have obtained similar results for the Mediterranean area at $6 \mathrm{kyr}$ BP based an inverse modelling method which use a vegetation model type Biome 4 (Guiot et al., 2000).

The cooling and drying trend which began in MidHolocene continues to $4 \mathrm{kyr}$ BP in Northeast Atlantic and Mediterranean (Marchal et al., 2002).

\subsubsection{The 8.2 ka event and others short-term Holocene events}

A short-lived cooling event occurs in Alboran and Aegean Seas between 8.4-8.2 kyr BP in our reconstructions, and could correspond to the regional expression of the $8.2 \mathrm{ka}$ event well known from ice, marine and terrestrial archives in the Northern hemisphere (e.g. Von Grafenstein et al., 1998; Mayewski et al., 2004; Alley and Agustsdottir, 2005). The duration of this event is 150 to 300 years (Thomas et al., 2007; Seppä et al., 2007). These temperature and precipitation anomalies of the $8.2 \mathrm{ka}$ event are explained by largescale changes in the atmospheric circulation resulting from a meltwater outflow into the North Atlantic Ocean and slowdown in North Atlantic deep-water formation (Barber et al., 1999; Rohling and Pälike, 2005).

The timing of the Sapropel S1 interruption in the Aegean Sea core clearly coincides with the $8.2 \mathrm{ka}$ event (Kotthoff et al., 2008b). The precipitation signals inferred from our reconstructions indicate that the $8.2 \mathrm{ka}$ event resulted in drier conditions in the borderlands of the Alboran and Aegean Seas (Fig. 5). For the Aegean region, this finding is in agreement with existing model simulations (Renssen et al., 2001; Wiersma and Renssen, 2006) as well as with terrestrial (Kotthoff et al., 2008b; Pross et al., 2009) and marine (Rohling et al., 2002) proxy data. This pattern also is consistent with various studies for the Northern hemisphere (Magny et al., 2003; Alley and Agustsdottir, 2005).

The temperature anomalies recorded in the Aegean and the Alboran Sea cores during the winter and summer are around $-3^{\circ} \mathrm{C}$. Thus, their magnitudes are similar to the cooling observed at Lake Maliq in the Balkans (Bordon et al., 2009), at Tenaghi Philippon in Grecce (Pross et al., 2009) and at Ammersee in Central Europe (Von Grafenstein et al., 1998). The 8.2 ka event was particularly significant for summer temperatures with a drop of $\sim 4^{\circ} \mathrm{C}$ in the Western Mediterranean (Pérez-Folgado et al., 2003) and values of $\sim 1-2^{\circ} \mathrm{C}$ elsewhere in Europe (Alley and Agustsdottir, 2005). The summer anomaly in this study is in agreement with Pérez-Folgado et al. (2003) but the summer drop is smaller than the winter anomaly in this study. 


\section{ODP Leg 161 site 976 - Alboran Sea}

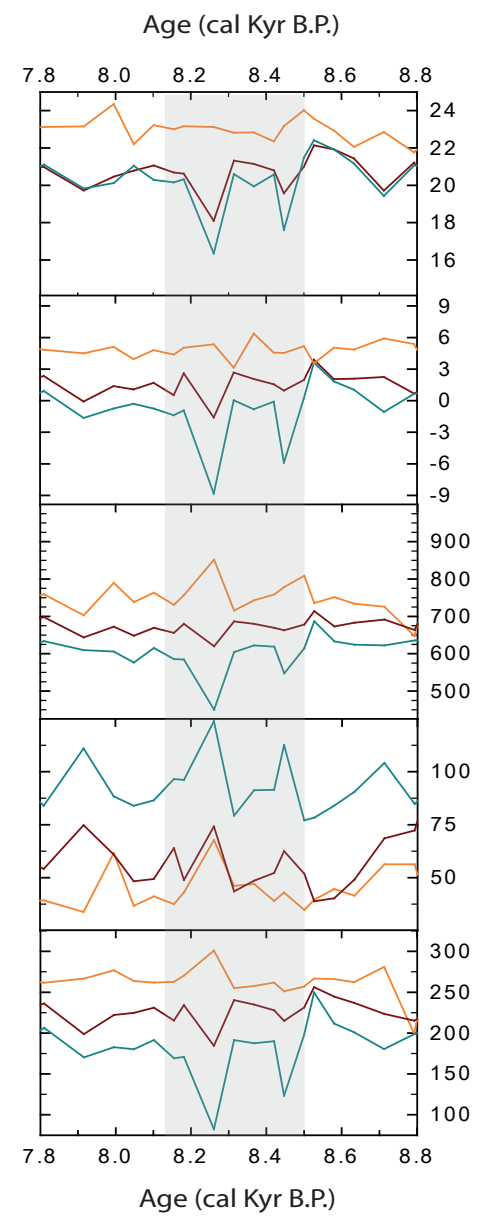

\section{GeoTü SL 152 - Aegean Sea}

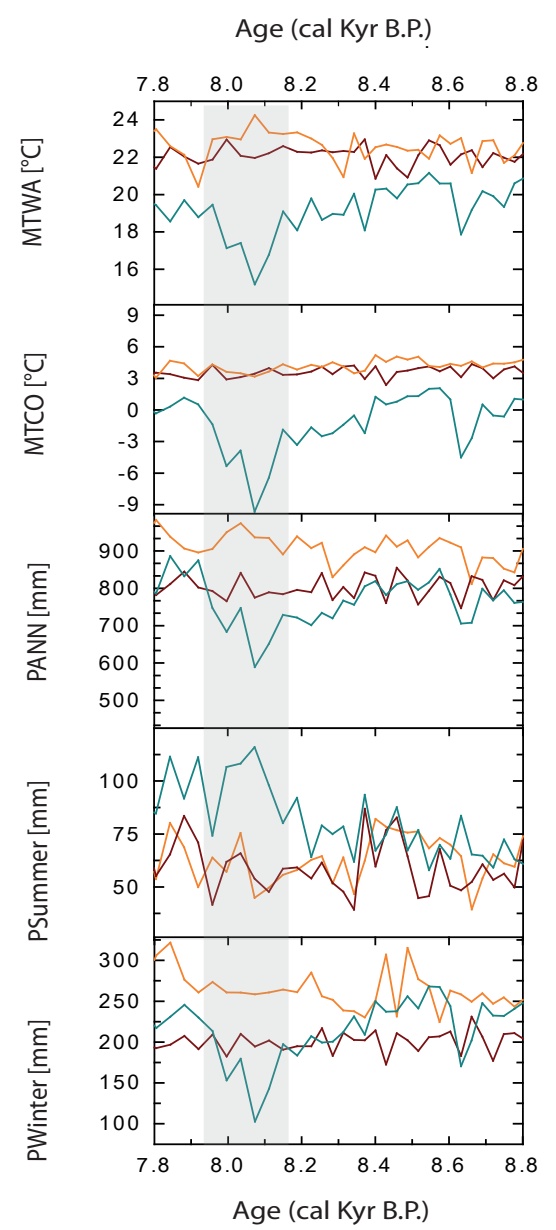

- PLS Method - GAM Method
- MAT Method

Fig. 5. Expression of the $8.2 \mathrm{ka}$ event as reconstructed from the pollen records of cores ODP Leg 161 Site 976 and SL 152 . Climatic parameters presented are mean temperature of the warmest month (MTWA), mean temperature of the coldest month (MTCO), annual precipitation (PANN), summer precipitation (PSummer) and winter precipitation (PWinter) estimated. The RMSE values for MAT are 2.55 for MTWA, 4.02 for MTCO, 186.70 for PANN, 16.01 for PSummer and 27.02 for PWinter. The RMSEP values for NMDS/GAM and PLS (in this order) are 3.04 and 3.68 for MTWA, 4.94 and 6.39 for MTCO, 227.27 and 271.92 for PANN, 50.39 and 67.52 for PSummer, and 77.69 and 91.59 for PWinter.

At both sites, the amplitude of variations associated with the $8.2 \mathrm{ka}$ event is stronger for the PLS model and comparable for MAT and NMDS/GAM model. In Alboran Sea, the same variation has been observed with the PLS and NMDS/GAM. In Aegean Sea, the trend of the event is difficult to observed, because the PLS anomalies are more marked. Wet summer conditions are suggested for the $8.2 \mathrm{ka}$ event, but the climate pattern of the summer precipitation seems not really clear during this period (PLS indicate wet conditions, while MAT and NMDS/GAM indicate dry conditions for the Aegean sea). More studies are required to clarify this pattern.
During the Holocene, five additional short-lived cool and dry events are indicated during for the intervals 11.2-10.8 kyr BP (Figs. 3 and 4, event 8), 10.4-10.2 kyr BP (Figs. 3 and 4, event 7), 9.5-9.6 kyr BP (Figs. 3 and 4, event 6), 8.4-8.0 kyr BP (Figs. 3 and 4, event 5 or $8.2 \mathrm{ka}$ ), 6.0-5.5 kyr BP (Figs. 3 and 4, event 4) and 5.9-4.2 kyr BP (Figs. 4, event 3 in the Aegean Sea). During these events, the winter and summer temperatures decrease slightly $\left(\sim 2^{\circ} \mathrm{C}\right)$ along with annual and winter precipitation values. Some of these events can be correlated with phases of lake-level changes described by Magny et al. (2002) in the Western Mediterranean around $11.5 \mathrm{kyr} \mathrm{BP}, 10.5 \mathrm{kyr} \mathrm{BP}, 9.0 \mathrm{kyr}$ BP 7.0 kyr BP, 4.0 kyr BP. The succession of these phases agrees 
well with the lake-level fluctuations at Lake Accesa (Italy) (Magny et al., 2007) and some of the events described by Jalut et al. (2000) in the Western Mediterranean. These events correspond to some of the Bond events centred at $11.1 \mathrm{kyr} \mathrm{BP}, 10.3 \mathrm{kyr} \mathrm{BP}, 9.5 \mathrm{kyr} \mathrm{BP}, 8.2 \mathrm{kyr} \mathrm{BP}, 5.9 \mathrm{kyr} \mathrm{BP}$ and $4.3 \mathrm{kyr}$ BP in the North Atlantic. The Holocene events appear to be the most recent manifestation of a pervasive millennial-scale climate cycle operating independently of the glacial-interglacial climate state (Bond et al., 1997).

The short Holocene cooling events such as the events marked 4, 5, 6, 7, and 8 (Figs. 3 and 4) are likely transmitted from the Atlantic Ocean to the Western Mediterranean Sea and the signal is amplified in the central Mediterranean settings (Cacho et al., 2002). During the short-term Holocene events we observed no precipitation differences between the Alboran and Aegean Sea records. This is in contrast to the precipitation gradient reconstructed during the Late-glacial events, such as the Older Dryas, Gerzensee Oscillation and GI-1c2.

In the Aegean Sea, two short-term cool and dry oscillations are also detected at $\sim 7.3$ and at $\sim 6.4 \mathrm{kyr} \mathrm{BP}$, the termination of Sapropel 1 formation. Similar short cooling events were detected using foraminiferal assemblages in the Adriactic Sea and the Aegean Sea at $7.5-7.0$ and 6.5-6.0 kyr BP (De Rijk et al., 1999; Geraga et al., 2000; Jimenez-Espejo et al., 2008).

The apparent timing of these short-lived events differs slightly between the two cores. This variation may be due to statistical uncertainties associated with the age models for each core. These uncertainties are dependent on the precision of radiocarbon dates, marine reservoir effects and on the calibration models themselves. Because of these uncertainties we established the timing and duration of these climate events independently between the two cores (Lowe et al., 2008).

\section{Comparison of methodologies applied, and reliability of the climate signal inferred}

Some indication of the relative reliability of the models can be obtained from the differences between model outputs. Clear differences in model response can be seen in several locations throughout the reconstructions, for example, the absence of a strong MTWA signal in the MAT model for the Aegean, during the $8.2 \mathrm{ka}$ event (Fig. 5), declines in NMDS/GAM PSummer values in the Alboran during the PBO, and generally dissimilar PLS results in all models. For both records the variability of the NMDS/GAM model is lower than the variability of either the MAT or PLS model. While Guiot (1990) uses low variability as an indication of the reliability of model construction when testing MAT distance metrics, it is possible that, among these methods low variability for the NMDS/GAM model is a result of statistical artifacts of the method since the GAM function used has a relatively high smoothing penalty to avoid overfitting of the data. The MAT and NMDS/GAM models appear to have greater similarity to one another than to the PLS model. In general the PLS reconstructions are more sensitive to changes in one or two pollen taxa. For example the PLS reconstruction of PSummer for the Aegean Sea has a very high correlation to changes in Asteraceae $\left(r^{2}=0.82\right.$ for the PLS method compared to $r^{2}=0.17$ for NMDS/GAM) which are unlikely to be valid in reality given the regional nature of the pollen record and the complex landscape dynamics in the surrounding region.

The NMDS/GAM method shows a smoother trend of increasing precipitation through the early Holocene in the Aegean Sea and in general has lower correlations between individual pollen taxa and the precipitation reconstructions. Since pollen taxa are rank-weighted in the NMDS/GAM method to generate the initial ordination, it is unlikely that any one pollen taxon will dominate the climate signal. This combined signal results in a smoother trend curve, except in cases where rapid, multi-species responses to climate are seen. The NMDS/GAM method picks up rapid changes in climatic parameters in the Alboran Sea where the trend between the PLS and NMDS/GAM reconstructions are similar, but again, the NMDS/GAM method shows smaller variation about the trend, likely as a result of decreased sensitivity to a single pollen taxon.

Holocene climatic oscillations are less pronounced with the MAT and NMDS/GAM method than the PLS method in both sites. In the Aegean site, the results of the MAT are close to the NMDS/GAM curves while in the Alboran Sea, the MAT curve appears to overstate the MTWA, MTCO, PANN and PWinter. Lack of close analogue assemblages may be responsible for the strong differences between NMDS/GAM and MAT models and the PLS model. Since the PLS model relies more strongly on individual pollen taxa, it may be more effective in predicting climate parameters for regions that are poorly sampled in the dataset, whereas MAT and NMDS/GAM models use complete pollen assemblages to determine climate parameters. In the Alboran Sea, the pollen comes from both Southern Spain and Morocco (with the presence of Cedrus from Morocco's Mountains) thus there are likely to be less analogues in the European pollen dataset, potentially causing statistical artefacts in the reconstruction, and resulting in greater differences between the PLS model and the MAT and NMDS/GAM models.

To address model quality, we tested the root mean squared error (RMSE) for the three different model types, MAT, NMDS/GAM and PLS. To do this, we randomly selected $67 \%$ of the complete pollen dataset to build the pollen-based climate transfer functions and subsequently predicted the remaining 33\% of the dataset (ter Braak, 1995), this selection and modelling procedure was repeated fifty times for NMDS/GAM and PLS method to arrive at a mean RMSEP value with valid standard deviations. Using this method, we find that model error for modern pollen is lowest with 
Table 2. Root mean squared error for climate variables used in this study, based on bootstrapped models using data subsets consisting of $67 \%$ of the entire pollen dataset (1181 predicted values).

\begin{tabular}{lrrrrrr}
\hline \multirow{2}{*}{ Climate } & \multicolumn{2}{c}{ MAT } & \multicolumn{2}{c}{ NMDS/GAM } & \multicolumn{2}{c}{ PLS } \\
\cline { 2 - 7 } Variable & $R^{2}$ & RMSE & $R^{2}$ & RMSEP & $R^{2}$ & RMSEP \\
\hline MTWA & 0.87 & 2.55 & 0.85 & 3.04 & 0.84 & 3.68 \\
MTCO & 0.94 & 4.02 & 0.98 & 4.94 & 0.91 & 6.39 \\
PANN & 0.80 & 186.70 & 0.75 & 227.27 & 0.74 & 271.92 \\
PSummer & 0.87 & 16.01 & 0.78 & 50.39 & 0.77 & 67.52 \\
PWinter & 0.78 & 27.02 & 0.76 & 77.69 & 0.75 & 91.59 \\
\hline
\end{tabular}

the MAT method for all climate parameters in this dataset (Table 2). Although NMDS/GAM appears to work better than MAT in situations where pollen samples are spatially sparse, or climatic gradients are sparsely sampled (Goring et al., 2009). However as coverage in a region increases and the number of potential analogues passes a threshold defined by local pollen variability, the MAT begins to perform better than NMDS/GAM. Although the PLS model has the highest RMSEP, it appears to be generally synchronous with the other models. However, the PLS model often has a much stronger amplitude in the pollen signal, perhaps an artifact of non-analogue climate parameters. It is interesting to note that even with relatively high RMSE values, all models are well correlated to the climate variables they reconstruct. This it can be relatively certain, that although the models show differing absolute magnitudes of temperature or precipitation, the general trend over time remain well reconstructed. It seems perhaps surprising that error for temperature and precipitation parameters are so high, however these values are somewhat lower than those reported by Brewer et al. (2008) for MTCO using PLS and MAT methods, although, strictly speaking the method for RMSE calculation differs between this paper and those in Brewer et al. (2008). Given the diversity of the pollen dataset and the broad climatic range, it is not surprising that the errors are so high. To ensure that there was no systematic bias in the prediction of error (for example, from the inclusion of steppe samples) we tested the spatial autocorrelation of RMSEP values using Moran's statistic (Cliff and Ord, 1981) and found no significant spatial autocorrelation (1_m $=0.007, p=0.630$ ). From this, we can conclude that the models used here perform well, and that there is no significant spatial bias in our pollen-based climate models. According to the results from modern and fossil data, the MAT and NMDS/GAM methods seem provide better results than the PLS method, which appears to provide spurious values in non-analogue situations.

Model error is calculated as the root mean squared error of prediction using leave-one-out cross validation for each method (Table 2). It is clear that a number of factors affect the predictive ability of each reconstruction method (for example Telford and Birks, 2005; Goring et al., 2009) thus, as statistical assumptions are violated, model performance will likely decline. Since it is difficult to predict the response of models to non-analogue conditions, especially for the multi-parameter climate data we are examining, we use model RMSEP as a guide to overall error. In general model error is large, this is in part a function of pollen-based climate models in general, but also of the extremely broad scale of Europe. The error terms incorporate error from across the continent, and thus may be inflated. It appears that MAT provides the best fit to underlying climate parameters. PLS regression appears to provide the lowest fit to the climate data for all parameters, with NMDS/GAM providing intermediate results.

\section{Conclusions}

This study aims to quantitatively reconstruct climatic trends and seasonality changes in the west and east Mediterranean region between 15000 and 4000 years BP. The palaeoclimate reconstructions are based on a new multi-method approach with three different and complementary methods: Modern Analogue Technique, Non-Metric Multidimensional Scaling/Generalized Additive Model and Partial Least Square regression.

The three methods produce patterns that show roughly similar trends throughout the pollen records of both sites. Some discrepancies can be seen in the amplitude of the climate reconstructions given that each method has their own set of advantages and limitations (Birks and Birks, 2006; Brewer et al., 2008). Cold and dry conditions prevailed during the Oldest and Younger Dryas. For the Younger Dryas, the reconstructions show a reduction in winter precipitation. More temperate conditions were established during the Lateglacial interstadial and continued through the Holocene with the establishment of a seasonal "Mediterranean" precipitation regime (hot dry summers and cool wet winters). A temperature and precipitation optimum is observed for the Early to mid-Holocene. Following the optimum of precipitation and temperature (after $7.8 \mathrm{kyr} \mathrm{BP}$ ), a progressive aridification and a slight decrease in temperature is recorded in both sites.

Evidence of strong climatic links between the North Atlantic and Mediterranean are found throughout the reconstructions. Evidence of events that have punctuated the deglaciation in the North Atlantic (such as Older Dryas, GI1c2, Gerzensee and Preboreal Oscillations and 8.2 ka event) appears in both the Aegean and Alboran Sea cores. These oscillations appear to have been stronger in the Aegean region than in the Alboran Sea. Our study suggests a West/East precipitation gradient across the Mediterranean region, with short-term climate changes being markedly stronger expressed and dryer in the Aegean region. 
Acknowledgements. Financial support for this study was provided by the French CNRS and the LAMA ANR project (MSHE Ledoux, USR 3124, CNRS), PICC and IDEGLACE ANR Projects. Simon Goring was funded by NSERC. We thank Ocean Driling Program for giving us samples of ODP Leg 161 Site 976 and J. P. Cazet and M. H. Castera help us for processing of samples of this core. UK and JP acknowledge support through the German Research Fundation (DFG, grant PR 651/6-1). This is LSCE contribution no. 4012. This paper is dedicated to our friend Dominique Jolly.

Edited by: D.-D. Rousseau

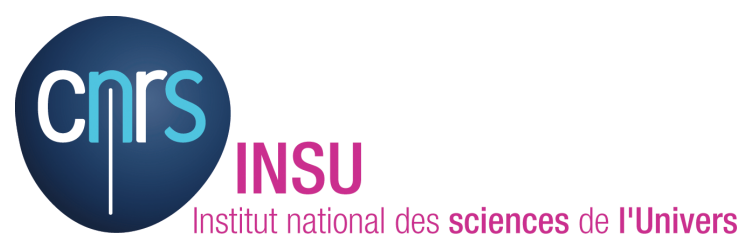

The publication of this article is financed by CNRS-INSU.

\section{References}

Allen, J. R. M., Long, A. J., Ottley, C. J., Graham Pearson, D., and Huntley, B.: Holocene climate variability in northernmost Europe, Quaternary Sci. Rev., 26, 1432-1453, 2007.

Alley, R. B., Marotzke, J., Nordhaus, W. D., Overpeck, J. T., Peteet, D. M., Pielke Jr., R. A., Pierrehumbert, T. R., Rhines, P. B., Stocker, T. F., Talley, L. D., and Wallace, J. M.: Abrupt climate change, Science, 299, 2005-2010, 2003.

Alley, R. B. and Agustsdottir, A. M.: The $8 \mathrm{k}$ event: cause and consequences of a major Holocene abrupt climate change, Quaternary Sci. Rev., 24, 1123-1149, 2005.

Ariztegui, D., Asioli, A., Lowe, J. J., Trincardi, F., Vigliotti, L., Tamburini, F., Chondrogianni, C., Accorsi, C. A., Bandini Mazzanti, M., Mercuri, A. M., Van der Kaars, S., McKenzie, J. A., and Oldfield, F.: Palaeoclimate and the formation of the sapropel S1: inferences from Late Quaternary lacustrine and marine sequences in the central Mediterranean region, Palaeogeogr. Palaeocl., 158, 215-240, 2000.

Asioli, A., Trincardi, F., Lowe, J. J., and Oldfield, F.: Shortterm climate changes during the last glacial-Holocene transition: Comparison between Mediterranean records and the GRIP event stratigraphy, J. Quaternary Sci., 14, 373-381, 1999.

Barber, D. C., Dyke, A., Hillaire-Marcel, C., Jennings, A. E., Andrews, J. T., Kerwin, M. W., Bilodeau, G., McNeely, R., Southon, J., Morehead, M. D., and Gagnon, J. M.: Forcing of the cold event of 8.200 years ago by catastrophic drainage of Laurentide lakes, Nature, 400, 344-348, 1999.

Bar-Matthews, M., Ayalon, A., Kaufman, A., and Wasserburg, G. J.: The Eastern Mediterranean paleoclimate as a reflection of regional events: Soreq cave, Israel, Earth Planet. Sc. Lett., 166, 85-95, 1999.

Bar-Matthews, M., Ayalon, A., and Kaufman, A.: Timing and hydrological conditions of Sapropel events in the Eastern Mediterranean, as evident from speleothems, Soreq cave, Israel, Chem. Geol., 169, 145-156, 2000.

Béthoux, J. P. and Prieur, L.: Hydrologie et circulation en Méditerranée Nord Occidentale, Ecologie des Microorganismes en Méditerranée Occidentale : ECOMED, Assoc. Franc. Tech. Petrole, 13-22, 1984.

Birks, H. H. and Birks, H. J. B.: Multi-proxy studies in palaeoclimnology, Veg. Hist. Archaeobot., 15, 235-251, doi:10.1007/s00334-006-0066-6, 2006.

Björck, S., Rundgren, M., Ingolfsson, O., and Funder, S.: The Preboreal oscillation around the Nordic seas: terrestrial and lacustrine responses. J. Quaternary Sci., 12, 455-465, 1997.

Björck, S., Walker, M. J. C., Cwynar, L. C., Johnsen, S., Knudsen, S., Lowe, J. J., Wohlfarth, B., and Intimate Members.: An event stratigraphy for the last Termination in the North Atlantic region based on the Greenland ice-core record: a proposal by the INTIMATE group, J. Quaternary Sci., 13, 283-292, 1998.

Bond, G., Showers, W., Cheseby, M., Lotti, R., Almasi, P., deMenocal, P., Priore, P., Cullen, H., Hajdas, I., and Bonani, G.: A Pervasive Millenial-Scale Cycle in North Atlantic Holocene and Glacial Climates, Science, 278, 1257-1266, 1997.

Bordon, A., Peyron, O., Lézine, A. M., Brewer, S., and Fouache, E.: Pollen-inferred Late-Glacial and Holocene climate in southern Balkans (Lake Maliq), Quatern. Int., 200, 19-30, 2009.

ter Braak, C. J. F. and Juggins, S.: Weighted averaging partial least squares regression (WA-PLS): an improved method for reconstructing environmental variables from species assemblages, Hydrobiologia, 269/270, 485-502, 1993.

ter Braak, C. J. F.: Non-linear methods for multivariate statistical calibration and their use in palaeoecology: a comparison of inverse (k-nearest neighbours, partial least squares and weighted averaging partial least squares) and classical approaches, Chemometr. Intell. Lab., 28, 165-180, 1995.

Brauer, A., Günter, C., Johsen, S. J., and Negendank, J. F. W.: Land-ice teleconnections of cold climatic periods during the last Glacial/Interglacial transition. Clim. Dynam., 16, 229-239, 2000.

Brewer, S., Guiot, J., and Barboni, D.: Pollen Methods and Studies, Use of Pollen as Climate Proxies, Enc. Quaternary Sci., 24972508, doi:10.1016/B0-44-452747-8/00177-0, 2007a.

Brewer, S., Guiot, J., and Torre, F.: Mid-Holocene climate change in Europe: a data-model comparison, Clim. Past, 3, 499-512, 2007, http://www.clim-past.net/3/499/2007/.

Brewer, S., Guiot, J., Sanchez-Goñi, M. F., and Klotz, S.: The climate in Europe during the Eemian: a multi-method approach using pollen data, Quaternary Sci. Rev., 27, 2303-2315, 2008.

Brewer, S., François, L., Cheddadi, R., Laurent, J.-M., and Favre, E.: Comparison of simulated and observed vegetation for the mid-Holocene in Europe, Clim. Past Discuss., 5, 965-1011, 2009 , http://www.clim-past-discuss.net/5/965/2009/.

Cacho, I., Grimalt, J. O., and Canals, M.: Response of the Western Mediterranean Sea to rapid climatic variability during the last 50000 years: a molecular biomarker approach, J. Marine Syst., 33/34, 253-272, 2002.

Cheddadi, R. and Rossignol-Strick, M.: Quaternary paleoclimates from pollen and isotope records of marine cores in the Nile cone area, Paleoceanography, 10, 291-300, 1995.

Cheddadi, R., Yu, G., Guiot, J., Harrison, S. P., and Prentice, I. C.: The climate of Europe 6000 years ago, Clim. Dynam., 13, 1-9, 1997.

Cheddadi, R., Guiot, J., and Jolly, D.: The Mediterranean vegeta- 
tion: what if the atmospheric $\mathrm{CO}_{2}$ increased?, Landscape Ecol., $16,667-675,2001$.

Cheddadi, R. and Bar-Hen, A.: Spatial gradient of temperature and potential vegetation feedback across Europe during the late Quaternary, Clim. Dynam., 32, 371-379, doi:10.1007/s00382-0080405-7, 2009.

Cliff, A. D. and Ord, J. K.: Spatial processes, Pion, 21 pp., 1981.

Colmenero-Hidalgo, E., Flores, J. A. and Sierro, F. J.: Biometry of Emiliania huxleyi and ist biostratigraphic significance in the Eastern North Atlantic Ocean and Western Mediterranean Sea in the last 20000 years, Mar. Micropaleontol., 46, 247-263, 2002.

Combourieu Nebout, N., Peyron, O., Dormoy, I., Desprat, S., Beaudouin, C., Kotthoff, U., and Marret, F.: Rapid climatic variability in the west Mediterranean during the last 25000 years from high resolution pollen data, Clim. Past, 5, 503-521, 2009, http://www.clim-past.net/5/503/2009/.

Combourieu-Nebout, N., Paterne, M., Turon, J. L., and Siani, G.: A high-resolution record of the last deglaciation in the Central Mediterranean Sea: Palaeovegetation and Palaeohydrological evolution, Quaternary Sci. Rev., 17, 303-317, 1998.

Combourieu-Nebout, N., Londeix, L., Baudin, F., Turon, J. L., von Grafenstein, R., and Zahn, R.: Quaternary marine and continental paleoenvironments in the Western Mediterranean (Site 976, Alboran Sea): palynological evidence, edited by: Zahn, R., Comas, M. C., and Klaus, A., Proc. ODP, College Station, TX (Ocean Drilling Program), Sci. Results, 161, 457-468, 1999.

Combourieu-Nebout, N., Turon, J. L., Zahn, R., Capotondi, L., Londeix, L., and Pahnke, K.: Enhanced aridity and atmospheric high-pressure stability over the western Mediterranean during the North Atlantic cold events of the past $50 \mathrm{ky}$, Geology, 30, 863866, 2002.

Davis, B. A. S., Brewer, S., Stevenson, A. C., and Guiot, J.: The temperature of Europe during the Holocene reconstructed from pollen data, Quaternary Sci. Rev., 22, 1701-1716, 2003.

Davis, B. A. S. and Stevenson, A. C.: The 8.2 ka event and EarlyMid Holocene forests, fires and flooding in the Central Ebro Desert, NE Spain, Quaternary Sci. Rev., 26, 1695-1712, 2007.

Davis, B. A. S. and Brewer, S.: Orbital forcing and role of the latitudinal insolation/temperature gradient, Clim. Dynam., 32, 143165, doi:10.1007/s00382-008-0480-9, 2009.

Denton, G. H., Alley R. B., Comer, G. C., and Broecker, W. S.: The role of seasonality in abrupt climate change, Quaternary Sci. Rev., 24, 1159-1182, 2005.

De Rijk, S., Hayes, A., and Rohling, E. J.: Eastern Mediterranean sapropel S1 interruption: an expression of the onset of climatic deteriortion around 7 ka B.P., Mar. Geol., 153, 337-343, 1999.

Drescher-Schneider, R., De Beaulieu, J. L., Magny, M., WalterSimonnet, A. V., Bossuet, G., Millet, L., Brugiapaglia, E., and Drescher, A.: Vegetation history, climate and human impact over the last 15000 years at Lago dell'Accesa (Tuscany, Central Italy), Veg. Hist. Archaeobot., 16, 279-299, 2007.

Emeis, K. C., Struck, U., Schulz, H. M., Rosenberg, R., Bernasconi, S., Erlenkeuser, H., Sakamoto, T., and Martinez-Ruiz, F.: Temperature and salinity variations of Mediterranean Sea surface waters over the last 16000 years from records of planktonic stable oxygen isotopes and alkenone unsaturation ratios, Palaeogeogr. Palaeocl., 158, 259-280, 2000.

Faegri, K. and Iversen, J.: Textbook of Pollen Analysis, Munksgaard, Copenhagen, Danemark, 237 pp., 1964.
Fairbanks, R. G., Mortlock, R. A., Chiu, T. C., Cao, L., Kaplan, A., Guilderson, T. P., Fairbanks, T. W., Bloom, T. W., Bloom, A. L., Grootes, P. M., and Nadeau M. J.: Radiocarbon calibration curve spanning 0 to 50000 years B.P. based on paired ${ }^{230} \mathrm{Th} /{ }^{234} \mathrm{U}$ and ${ }^{14} \mathrm{C}$ dates on pristine corals, Quaternary Sci. Rev., 24, 17811796, 2005.

Favaretto, S., Asioli, A., Miola, A., and Piva, A.: Preboreal climatic oscillations recorded by pollen and foraminifera in the southern Adriatic Sea, Quatern. Int., 190(1), 89-102, 2008.

Fletcher, W. J. and Sanchez-Goñi, M. F.: Orbital- and sub-orbitalscale climate impacts on vegetation of the western Mediterranean basin over the last $48000 \mathrm{yr}$, Quaternary Res., 70(3), 451-464, 2008.

Geraga, M., Tsaila-Monopolis, S., Ioakim, C., Papatheodorou, G., and Ferentinos, G.: Evaluation of palaeoenvironmental changes during the last 18000 years in the Myrtoon basin, SW Aegean Sea, Palaeogeogr. Palaeocl., 156, 1-17, 2000.

Goring, S., Pellatt, M. G., Lacourse, T., Walker, I. R., and Mathewes, R. W.: A new methodology for reconstructing climate and vegetation from modern pollen assemblages: an example from British Columbia, J. Biogeogr., 36, 626-638, doi:110.1111/j.1365-2699.02021.x, 2009.

Grafenstein, V., Erlenkeuser, U., Müller, H., Jouzel, J., and Johnsen, S.: The cold event 8200 years ago documented in oxygen isotope records of precipitation in Europe and Greenland, Clim. Dynam., 14, 73-81, 1998.

Guiot, J.: Methodology of the last climatic cycle reconstruction in France from pollen data, Palaeogeogr. Palaeocl., 80, 49-69, 1990.

Guiot, J., Torre, F., Jolly, D., Peyron, O., Boreux, J. J., and Cheddadi, R.: Inverse vegetation modelling by Monte Carlo sampling to reconstruct palaeoclimates under changed precipitation seasonality and $\mathrm{CO}_{2}$ conditions: application to glacial climate in Mediterranean region, Ecol. Model., 127, 119-140, 2000.

Heiri, O., Cremer, H., Engels, S., Hoek, W. Z., Peeters, W., and Lotter, A. F.: Lateglacial summer temperatures in the Northwest European lowlands: a chironomid record from Hijkermeer, The Netherlands, Quaternary Sci. Rev., 26, 2420-2437, 2007.

Huntley, B., Watts, W. A., Allen, J. R. M., and Zolitschka, B.: Palaeoclimate, chronology and vegetation history of the Weichselian Lateglacial: comparative analysis of data from three cores at Lago Grande di Monticchio, Southern Italy, Quaternary Sci. Rev., 18, 945-960, 1999.

IPCC 2007, Climate Change 2007: Synthesis Report, Contribution of Working Groups I, II and III to the Fourth Assessment Report of the Intergovernmental Panel on Climate Change, edited by: Core Writing Team, Pachauri, R. K., and Reisinger, A., IPCC, Geneva, Switzerland, 104 pp., 2007.

Jalut, G., Amat, A. E., Bonnet, L., Gauquelin, T., and Fontugne, M.: Holocene climatic changes in the Western Mediterranean, from south-east France to south-east Spain, Palaeogeogr. Palaeocl., 160, 255-290, 2000.

Jalut, G., Dedoubat, J. J., Fontugne, M., and Otto, T.: Holocene circum-Mediterranean vegetation changes: Climate forcing and human impact, Quatern. Int., 200, 4-18, 2009.

Jimenez-Espejo, F. J., Martinez-Ruiz, F., Rogerson, M., GonzàlezDonoso, J. M., Romero, O. E., Linares, D., Sakamoto, T., Gallego-Torres, D., Rueda Ruiz, J. L., Ortega-Huertas, M., and Perez Claros, J. A.: Detrital input, productivity fluctuations, and 
water mass circulation in the westernmost Mediterranean Sea since the Last Glacial Maximum, Geochem. Geophy. Geosy., 9, Q11U02, doi:10.1029/2008GC002096, 2008.

Jorissen, F. J., Asioli, A., Borsetti, A. M., Capotondi, L., De Visser, J. P., Hilgen, F. J., Rohling, E. J., Van der Borg, K., Vergnaud Grazzini, C., and Zachariasse, W. J.: Late Quaternary central Mediterranean biochronology, Mar. Micropalaeontol., 21, 169189,1993

Kageyama, M., Combourieu-Nebout, N., Sepulchre, P., Peyron, O., Krinner, G., Ramstein, G., and Cazet, J. P.: The Last Maximum and Heinrich Event 1 in terms of climate and vegetation around the Alboran Sea: a preliminary model-data comparison, C. R. Geoscience, 337, 983-992, 2005.

Kallel, N., Paterne, M., Labeyrie, L., Duplessy, J. C., and Arnold, M.: Temperature and salinity of the Tyrrhenian Sea during the last 18000 years, Palaeogeogr. Palaeocl., 135, 97-108, 1997.

Kotthoff, U., Müller, U. C., Pross, J., Schmiedl, G., Van de Schootbrugge, B., Lawson, I., and Schulz, H.: Lateglacial and Holocene vegetation dynamics in the Aegean region: An integrated view based on pollen data from marine and terrestrial archives, The Holocene, 18, 1019-1032, 2008a.

Kotthoff, U., Pross, J., Müller, U. C., Peyron, O., Schmiedl, G., Schulz, H., and Bordon, A.: Climate dynamics in the borderlands of the Aegean Sea during formation of Sapropel S1 deduced from a marine pollen record, Quaternary Sci. Rev., 27, 832-845, 2008b.

Larocque, I. and Finsinger, W.: Late-glacial chironomid-based temperature reconstructions for Lago Piccolo di Avigliana in the southwestern Alps (Italy), Palaeogeogr. Palaeocl., 257, 207-223, 2008.

Lawson, I., Frogley, M., Bryant, C., Preece, R., and Tzedakis, P.: The Lateglacial and Holocene environmental history of the Ioannina basin, north-west Greece, Quaternary Sci. Rev., 23, 15991625, 2004.

Lionello, P., Malanotte-Rizzoli, P., and Boscolo, R.: Mediterranean Climate Variability, Elsevier BV, Amsterdam, The Netherlands, 421 pp., 2006.

Lotter, A. F., Eicher, U., Siegenthaler, U., and Birks, H. J. B.: Lateglacial climatic oscillations as recorded in Swiss lake sediments, J. Quaternary Sci., 7, 187-204, 1992.

Lotter, A. F., Birks, H., Eicher, U., Hofmann, W., Schwander, J., and Wick, L.: Younger Dryas and Allerød summer temperatures at Gerzensee (Switzerland) inferred from fossil pollen and cladoceran assemblages, Palaeogeogr. Palaeocl., 159, 349-361, 2000.

Lowe, J. J., Rasmussen, S. O., Björck, S., Hoek, W. Z., Steffensen, J. P., Walker, M. J. C., Yu, Z. C., and the INTIMATE group: Synchronisation of palaeoenvironmental events in the North Atlantic region during the Last Termination: a revised protocol recommended by the INTIMATE group, Quaternary Sci. Rev., 27, 6-17, 2008.

Magny, M., Miramont, C., and Sivan, O.: Assessment of the impact of climate and anthropogenic factors on Holocene Mediterranean vegetation in Europe on the basis of palaeohydrological records, Palaeogeogr. Palaeocl., 186, 47-59, 2002.

Magny, M., Bégeot, C., Guiot, J., and Peyron, O.: Contrasting patterns of hydrological changes in Europe in response to Holocene climate cooling phases, Quaternary Sci. Rev., 22, 1589-1596, 2003.

Magny, M., Aalbersberg, G., Bégeot, C., Benoit-Ruffaldi, P.,
Bossuet, G., Disnar, J. R., Heiri, O., Laggoun-Defarge, F., Mazier, F., Millet, L., Peyron, O., Vannière, B., and WalterSimonet, A. V.: Environmental and climatic changes in the Jura mountains (eastern France) during the Lateglacial-Holocene transition: a multi-proxy record from Lake Lautrey, Quaternary Sci. Rev., 25, 414-445, 2006a.

Magny, M., De Beaulieu, J. L., Drescher-Schneider, R., Vannière, B., Walter-Simonnet, A. V., Millet, L., Bossuet, G., and Peyron, O.: Climatic oscillations in central Italy during the Last GlacialHolocene transition: the record from Lake Accesa, J. Quaternary Sci., 21, 1-10, 2006b.

Magny, M., De Beaulieu, J. L., Drescher-Schneider, R., Vannière, B., Walter-Simonnet, A. V., Miras, Y., Millet, L., Bossuet, G., Peyron, O., Brugiapaglia, E., and Leroux, A.: Holocene climate changes in the central Mediterranean as recorded by lake-level fluctuations at Lake Accesa (Tuscany, Italy), Quaternary Sci. Rev., 26, 1736-1758, 2007.

Marchal, O., Cacho, I., Stocker, T. F., Grimalt, J. O., Calvo, E., Martrat, B., Shackleton, N., Vautravers, M., Cortijo, E., Van Kreveld, S., Andersson, C., Koç, N., Chapman, M., Sbaffi, L., Duplessy, J. C., Sarnthein, M., Turon, J. L., Duprat, J., and Jansen, E.: Apparent long-term cooling of the sea surface in the northeast Atlantic and Mediterranean during the Holocene, Quaternary Sci. Rev., 21, 455-483, 2002.

Mayewski, P. A., Rohling, E. J., Stager, J. C., Karlén, W., Maasch, K. A., Meeker, L. D., Meyerson, E. A., Gasse, F., Van Kreveld, S., Holmgren, K., Lee-Thorp, J., Rosqvist, G., Rack, F., Staubwasser, M., Schneider, R., and Steig, E.: Holocene climate variability, Quaternary Res., 62, 243-255, 2004.

Mercone, D., Thomson, J., Croudace, I. W., Siani, G., Paterne, M., and Troelstra, S.: Duration of S1, the most recent sapropel in the eastern Mediterranean Sea, as indicated by accelerator mass spectrometry radiocarbon and geochemical evidence, Paleoceanography, 15, 336-347, 2000.

Mudie, P. J., Rochon, A., and Aksu, A. E.: Pollen stratigraphy of Late Quaternary cores from Marmara Sea: land-sea correlation and paleoclimatic history, Mar. Geol., 190, 233-260, 2002.

Myers, P. G. and Rohling, E. J.: Modeling a 200-Yr Interruption of the Holocene Sapropel $S_{1}$, Quaternary Res., 53, 98-104, doi:10.1006/qres.1999.2100, 2000 .

Naughton, F., Sanchez-Goñi, M. F., Desprat, S., Turon, J. L., Duprat, J., Malaizé, B., Joli, C., Cortijo, E., Drago, T., and Freitas, M. C.: Present-day and past (last 25000 years) marine pollen signal off western Iberia, Mar. Micropaleontol., 62, 91$114,2007$.

North Greenland Ice Core Project members: North Greenland Ice Core Project Oxygen Isotope Data, IGBP Pages/Word Data Center for Paleoclimatology Data Contribution Series \#2004-059, NOAA/NGDC Paleoclimatology Program, Boulder CO, USA, 2004.

Pérez-Folgado, M., Sierro, F. J., Flores, J. A., Cacho, I., Grimalt, J. O., Zahn, R., and Shackleton, N.: Western Mediterranean planktonic foraminifera events and millennial climatic variability during the last $70 \mathrm{kyr}$, Mar. Micropaleontol., 48, 49-70, 2003.

Petit-Maire, N. and Vrielinck, B.: The Mediterranean basin: the last two climatic extremes: explanatory notes of the maps, Andra Ed, Paris, France, 98 pp., 2005.

Peyron, O., Jolly, D., Bonnefille, R., Vincens, A., and Guiot, J.: Climate of East Africa $6000{ }^{14} \mathrm{C}$ yr B.P., as inferred from pollen 
data, Quaternary Res., 54, 90-101, 2000.

Peyron, O., Bégeot, C., Brewer, S., Heiri, O., Magny, M., Millet, L., Ruffaldi, P., Van Campo, E., and Yu, G.: Late-Glacial climatic changes in Eastern France (Lake Lautrey) from pollen, lakelevels, and chironomids, Quaternary Res., 64, 197-211, 2005.

Peyron, O., Jolly, D., Braconnot, P., Bonnefille, R., Guiot, G., Wirmann, D., and Chalié, F.: Quantitative reconstructions of annual rainfall in Africa 6000 years ago: Model-data comparison, J. Geophys., Res., 111, D24110, doi:D2411010.1029/2006JD007396, 2006.

Pons, A. and Reille, M.: The Holocene and Upper Pleistocene pollen records from Padul (Granada, Spain): a new study, Palaeogeogr. Palaeocl., 66, 243-263, 1988.

Prentice, I. C., Guiot, J., Huntley, B., Jolly, D., and Cheddadi, R.: Reconstructing biomes from palaeocological data: a general method and its application to European pollen data at 0 to $6 \mathrm{ka}$, Clim. Dynam., 12, 185-194, 1996.

Pross, J., Kotthoff, U., Müller, U. C., Peyron, O., Dormoy, I., Schmiedl, G., Kalaitzidis, S., and Smith, A.: Massive perturbation in terrestrial ecosystems of the Eastern Mediterranean region associated with the $8.2 \mathrm{kyr}$ climatic event, Geology, 37, 887-890, 2009.

Quézel, P. and Médail, F.: Ecologie et biogéographie des forêts du basin méditerranéen, Elsevier-Lavoisier eds, Paris, France, 571 pp., 2003.

Rasmussen, S. O., Andersen, K. K., Svensson, A. M., Steffensen, J. P., Vinther, B. M., Clausen, H. B., Siggaard-Andersen, M. L., Johnsen, S. J., Larsen, L. B., Dahl-Jensen, D., Bigler, M., Röthlisberger, R., Fischer, H., Goto-Azuma, K., Hansson, M. E., and Ruth, U.: A new Greenland ice core chronology for the last glacial termination, J. Geophys. Res., 111, D06102, doi:10.1029/2005JD006079, 2006.

Renssen, H. and Isarin, R. F. B.: The two major warming phases of the last deglaciation at $\sim 14.7$ and $\sim 11.5$ ka cal B.P. in Europe: climate reconstructions and AGCM experiments, Global Planet. Change, 30, 117-153, 2001.

Renssen, H., Isarin, R. F. B., Jacob, D., Podzun, R., and Vandenberghe, J.: Simulation of the Younger Dryas climate in Europe using a regional climate model nested in an AGCM: preliminary results, Global Planet. Change, 30, 41-57, 2001.

Roberts, N., Reed, J. M., Leng, M. J., Kuzucuoglu, C., Fontugne, M., Bertaux, J., Woldring, H., Bottema, S., Black, S., Hunt, E., and Karabiyikoglu, M.: The tempo of Holocene climatic change in the eastern Mediterranean region: new high-resolution craterlake sediment data from central Turkey, The Holocene, 11(6), 721-736, 2001.

Rohling, E. J. and De Rijk, S.: Holocene Climate Optimum and Last Glacial Maximum in the Mediterranean: the marine oxygen isotope record, Mar. Geol., 153, 57-75, 1999.

Rohling, E. J., Cane, T. R., Cooke, S., Sprovieri, M., Bouloubassi, I., Emeis, K. C., Schiebel, R., Kroon, D., Jorissen, F. J., Lorre, A., and Kemp, A. E. S.: African monsoon variability during the previous interglacial maximum, Earth Planet. Sc. Lett., 202, 6175, 2002.

Rohling, E. J. and Pälike, H.: Centennial-scale climate cooling with a sudden cold event around 8200 years ago, Nature, 434, 975979, 2005.
Rossignol-Strick, M.: The Holocene climatic optimum and pollen records of sapropel 1 in the eastern Mediterranean, 90006000 B.P., Quaternary Sci. Rev., 18, 515-530, 1999.

Sbaffi, L., Wezel, F. C., Kallel, N., Paterne, M., Cacho, I., Ziveri, P., and Shackleton, N.: Response of the pelagic environment to palaeoclimatic changes in the central Mediterranean Sea during the Late Quaternary, Mar. Geol., 178, 39-62, 2001.

Seppä, H., Birks, H. J. B., Giesecke, T., Hammarlund, D., Alenius, T., Antonsson, K., Bjune, A. E., Heikkilä, M., MacDonald, G. M., Ojala, A. E. K., Telford, R. J., and Veski, S.: Spatial structure of the 8200 cal yr B.P. event in northern Europe, Clim. Past, 3, 225-236, 2007, http://www.clim-past.net/3/225/2007/.

Siani, G., Paterne, M., Michel, E., Sulpizio, R., Sbrana, A., Arnold, M., and Haddad, G.: Mediterranean Sea surface radiocarbon reservoir age changes since the Last Glacial Maximum, Science, 294, 1917-1920, 2001.

Stuiver, M., Reimer, P. J., Bard, E., Beck, J. W., Burr, G. S., Hughen, K. A., Kromer, B., McCormac, G., Van Der Plicht, J., and Spurk, M.: Radiocarbon age calibration, $24000-0$ cal B.P., Radiocarbon, 40, 1041-1083, 1998.

Thomas, E. R., Wolff, E. W., Mulvaney, R., Steffensen, J. P., Johnsen, S. J., Arrowsmith, C., White, J. W. C., Vaughn, B., and Popp, T.: The $8.2 \mathrm{ka}$ event from Greenland ice cores, Quaternary Sci. Rev., 26, 70-81, 2007.

Telford, R. J. and Birks, H. J. B.: The secret assumption of transfer functions: problems with spatial performance, Quaternary Sci. Rev., 24, 2173-2179, doi:10.1016/j.quascirev.2005.05.001, 2005.

Tzedakis, P. C.: Seven ambiguities in the Mediterranean palaeoenvironmental narrative, Quaternary Sci. Rev., 26, 2042-2066, 2007.

Wiersma, A. P. and Renssen, H.: Model-data comparison for the 8.2 ka B.P. event: confirmation of a forcing mechanism by catastrophic drainage of Laurentide Lakes, Quaternary Sci. Rev., 25, 63-88, 2006.

Wijmstra, T. A.: Palynology on the first 30 meters of a $120 \mathrm{~m}$ deep section in Northern Greece, Acta. Bot. Neerl., 18, 511-526, 1969.

Wold, S., Ruhe, A., Wold, H., and Dunn III, W. J.: The colinearity problem in linear regression, the partial least squares (PLS) approach to generalized inverses, SIAM, J. Sci. and Stat. Comput. 5, 735-743, 1984.

Wu, H., Guiot, J., Brewer, S., and Guo, Z.: Climatic changes in Eurasia and Africa at the last glacial maximum and mid-Holocene: reconstruction from pollen data using inverse vegetation modelling, Clim. Dynam., 29, 211-229, doi10.1007/s00382-007-0231-3, 2007.

Zanchetta, G., Drysdale, R. N., Hellstrom, J. C., Fallick, A. E., Isola, I., Gagan, M. K., and Pareschi, M. T.: Enhanced rainfall in the Western Mediterranean during deposition of sapropel S1: stalagmite evidence from Corchia cave (Central Italy), Quaternary Sci. Rev., 26, 279-286, 2007.

Zonneveld, K. A. F.: Palaeoclimatic reconstruction of the last deglaciation (18-8 ka B.P.) in the Adriatic Sea region; a landsea correlation based on palynological evidence, Palaeogeogr. Palaeocl., 122, 89-106, 1996. 